\author{
Contato \\ Rua ltapeva, $474-13^{\circ}$ andar \\ 01332-000 - São Paulo - SP \\ silvanajeha@gmail.com
}

\section{GANHAR A VIDA. UMA HISTÓRIA DO BARBEIRO AFRICANO ANTÔNIO JOSÉ DUTRA E SUA FAMÍLIA. RIO DE JANEIRO, SÉCULO XIX}

\author{
Silvana Jeha** \\ Fundação Getúlio Vargas \\ São Paulo - São Paulo - Brasil
}

\title{
Resumo
}

Este artigo versa sobre as artes dos barbeiros-sangradores e músicos no Rio de Janeiro oitocentista, centrado na história de um deles: Antonio José Dutra. O texto também esboça traços biográficos de seus herdeiros. O patriarca, natural do Reino do Congo, veio escravo para o Brasil e obteve alforria no início da década de 1820. Em 1849, quando morreu, possuía uma barbearia, uma banda, 13 escravos e dois imóveis. Era pai de seis filhos naturais, frutos de três relacionamentos. Se, por um lado, os filhos não lograram o mesmo sucesso do pai, por outro, o seu legado cultural e financeiro foi fundamental para suas vidas remediadas de negros livres numa sociedade escravista.

\section{Palavras-chave}

SéculoXIX-RiodeJaneiro-barbeiros-sangradores-famílianegra-bandademúsica.

* Este artigo é uma versão profundamente modificada e acrescida de novas pesquisas do meu texto homônimo publicado no CD-Rom: PORTO, Angela. Doenças e escravidão: Sistema de saúde e práticas terapêuticas. Rio de Janeiro: Casa de Oswaldo Cruz/ Fiocruz, 2007. Escrever sobre Antônio José Dutra e sua família está intrinsicamente ligado à minha participação como assistente de pesquisa do professor Zephyr Frank no projeto "Roots of inequality: wealthholding in Southeasthern Brazil, 19th century". Frank publicou em 2004 o livro Dutras's world: Wealth and family in nineteenth century Rio de Janeiro (Entre ricos e pobres: O mundo de Antônio José Dutra no Rio de Janeiro oitocentista, traduzido no Brasil em 2012) sobre a inserção de Antônio José Dutra na ordem social da Corte. Eu enveredei pelos meandros familiares e culturais de sua história e de seus filhos.

** Pós-doutoranda na Escola de Economia de São Paulo/FGV. 
Rua ltapeva, $474-13^{\circ}$ andar $01332-000$ - São Paulo - SP silvanajeha@gmail.com
"GANHAR A VIDA".

A STORY OF THE

AFRICAN ANTÔNIO

JOSÉ DUTRA AND

HIS FAMILY. RIO

DE JANEIRO, 19TH CENTURY

\section{Silvana Jeha}

Fundação Getúlio Vargas

São Paulo - São Paulo - Brasil

\begin{abstract}
This article is about the arts of barbers who were also bleeders and musicians, centered on the story of one of them: Antonio José Dutra. The text also outlines biographical traits of his heirs. The patriarch "natural from the Kingdom of the Congo", obtained manumission in earlies 1820s. In 1849, when he died, he had a barber shop, a band, 13 slaves and two properties. He was the father of six natural children, born of three relationships. On one hand, the children have failed the same success of the father, on the other, his cultural financial legacy was crucial to ther modest lives of free blacks in a slave society.
\end{abstract}

\title{
Keywords
}

19th century - Rio de Janeiro - barbers-surgeons - black family - music band. 


\begin{abstract}
Sou católico romano natural do Reino de Congo e batizado na Freguesia de Nossa Senhora dos Remédios da Cidade de Angola e nunca conheci meus pais. Sou viúvo de Maria Roza de Jesus de cujo matrimonio não houveram filhos, mas tenho seis naturais havidos depois de nomes Ignacia, casada com João Baptista da Silva, Manoel José Dutra e Alexandre Jose Dutra com Hilária Maria do Rozario, e Maria Leopoldina e outra por batizar com Ana Maria Mathildes que estão em minha companhia, as quais reconheço e por filhas e como tais os tenho criado e educado. ${ }^{1}$
\end{abstract}

Assim Antônio José Dutra - barbeiro sangrador, dentista e líder de banda - resumiu sua biografia familiar num testamento que escreveu dias antes de falecer em 1849.

Os barbeiros sangradores músicos na América portuguesa e no Império do Brasil, desde pelo menos o século XVIII, eram em sua maioria negros: escravos, libertos e livres; africanos e crioulos. Praticantes de uma tradição europeia medieval, com contornos ibéricos e depois locais, estes profissionais mistos de terapeutas populares, esteticistas, músicos e alfaiates - marcavam presença nos navios negreiros, fazendas, em pequenas cidades e sobretudo nas grandes cidades, tanto em suas lojas como no atendimento que faziam nas ruas, hospitais e residências.

Desde o século XVI, segundo Georgina dos Santos, já havia regulamentação para barbeiros em Portugal: "prescrita por médicos e executada por barbeiros, a sangria impôs-se e manteve-se como a soberana das técnicas de tratamento, nas tendas, nos domicílios, nos cárceres e nos hospitais lisboetas durante todo o período moderno". 2 O aprendizado da sangria "nada tinha de livresco ou teórico, era oral, empírico e obtido nas tendas dos mestres barbeiros". 3

A Fisicatura-mor foi a última instituição médica a ceder cartas para cirurgiões-barbeiros, conhecidos também como barbeiros sangradores ou apenas barbeiros. Sediada no Rio de Janeiro a partir de 1808, a instituição era "responsável pela regulamentação e fiscalização das diversas atividades relacionadas às práticas médicas em Portugal e todos os seus domínios". ${ }^{4} \mathrm{~A}$

\footnotetext{
1 Testamento de Antônio José Dutra. In: Traslado de apensos dos autos de inventário do finado Antônio José Dutra. Arquivo Nacional (doravante AN), caixa 2680, n. 341.

2 SANTOS, Georgina Silva dos. A arte de sangrar na Lisboa do Antigo Regime. Tempo, vol. 10, n. 19, Rio de Janeiro, jul 2005, p. 47.

3 Ibidem, p. 51.

${ }^{4}$ PIMENTA, Tânia Salgado, Barbeiros-sangradores e curandeiros no Brasil (1808-1828). Manguinhos - história, ciências, saúde vol. 5, n. 2. Rio de Janeiro, jul-out 1998, p. 351.
} 
carta com o carimbo do "Príncipe" autorizava em qualquer parte do reino praticar a dita arte, qual seja, "sangrar, sarjar [aplicar lancetas], lançar ventosas e sanguessugas por ordem do médico ou cirurgião aprovado". 5 A partir de 1828, quando a Fisicatura-mor foi extinta, os barbeiros e outros terapeutas seriam objetos de posturas da Câmara Municipal da Corte.

No hospital da Santa Casa de Misericórdia do Rio de Janeiro, as sangrias eram utilizadas em profusão. Ali, em 1838, 250 sanguessugas - também conhecidas como bichas - foram aplicadas num marinheiro russo para tratar uma peritonite resultante de um esfaqueamento. ${ }^{6} \mathrm{O}$ hospital fazia uma convocação pública para "aplicação de bichas", já que se gastava com elas "contos de réis"?

Entre 1844 e 1889, foram publicados mais de dois mil e quatrocentos anúncios no Almanack Laemmert de cerca de mil barbeiros sangradores residentes no Rio de Janeiro. ${ }^{8}$ Em 1889, na sua última edição durante o Império, estão listados quase duzentos nomes reunidos sob o título de "barbeiros e sangradores". Neste ano também havia anúncios de dois depósitos de bichas para sangrar. Ao longo do século XIX, os médicos prescreveram cada vez menos sangrias até serem praticamente extintas em algum momento do século XX.

Antônio José Dutra era atendido por médicos formados. Foram descontados das custas de seu inventário $118 \$ 000$ utilizados para pagar os médicos, o boticário e o barbeiro que lhe atenderam no leito de morte.? Durante o surto de febre amarela de 1850, todos os seus filhos e escravos foram tratados por "doutores". O doutor Antônio Dias da Costa era o médico da família. No inventário pós-mortem de Dutra são apresentados diversos gastos de 2\$000 réis com consultas a todos os órfãos e alguns dos escravos de seus filhos. Um outro médico atendeu Ignacia, a filha mais velha, durante um de seus abortos. Foi chamado enquanto uma parteira a ajudava. ${ }^{10}$

Dos 193 pedidos recebidos pela Fisicatura-mor para exercer a arte de sangrador - oriundos de toda a América portuguesa e depois do Império do Brasil - 101 eram de escravos e 63 eram de forros, somando 84\% do total. ${ }^{11}$

\footnotetext{
5 AN, Fisicatura-mor, códice 145, vol. 1, p. 53v-54.

6 GUIMARÃES, dr. Duas palavrinhas acerca da peritonite... Archivo Medico Brasileiro, Rio de Janeiro, outubro de 1845 , p. 36.

7 Diário do Rio de Janeiro, 26/8/1830.

8 PIMENTA, Tania \& DANTAS, Rodrigo A. Barbeiros-sangradores no Rio de Janeiro oitocentista: Transformações de um ofício. Revista da ABPN, vol. 6, n. 14, jul-out 2014, p. 16.

9 Inventário de Antônio José Dutra. AN, caixa 68, n. 171, p. 45.

${ }^{10}$ Embargo do inventário de Antônio José Dutra. AN, caixa 1143, n. 4622, f. 82.

11 PIMENTA, Tania Salgado. Barbeiros-sangradores e curandeiros no Brasil, op. cit., 1998, p. 355.
} 
Em Salvador, no período de 1741-49, de um total de 38 exames para barbeiros, todos os indivíduos eram negros ou mulatos escravos ou livres. ${ }^{12} \mathrm{Na}$ década de 1810 este fenômeno não passou despercebido pelo francês Jean Baptiste Debret que desenhou e descreveu uma loja de barbeiro, barbeiros ambulantes e um cirurgião negro:

O oficial de barbeiro no Brasil é quase sempre negro ou pelo menos mulato. Esse contraste chocante para o europeu não impede ao habitante do Rio de Janeiro entrar com confiança numa dessas lojas, certo de aí encontrar numa mesma pessoa um barbeiro hábil, um cabeleireiro exímio, um cirurgião familiarizado com o bisturi e um destro aplicador de sanguessugas. Dono de mil talentos, ele tanto é capaz de consertar a malha escapada de uma meia de seda, como de executar, no violão ou na clarineta, valsas e contradanças francesas, em verdade arranjadas a seu jeito. ${ }^{13}$

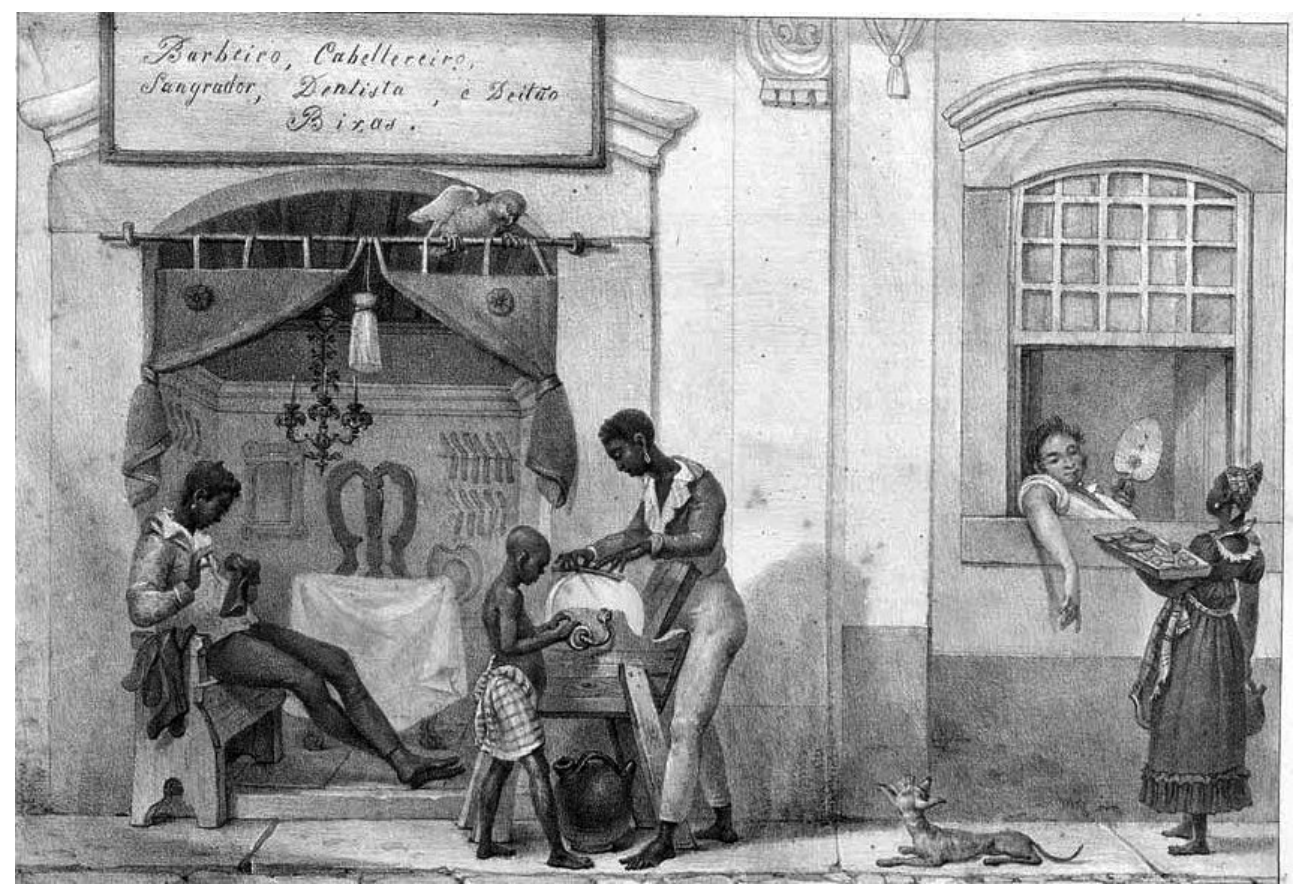

Também havia barbeiros brancos. Na Corte, em 1821, o barbeiro Chaves anunciava a contratação de um barbeiro necessariamente branco. Ele ensi-

\footnotetext{
${ }^{12}$ RUSSEL-WOOD, A.J.R. Escravos elibertos no Brasil colonial. Rio deJaneiro:Civilização Brasileira, 2005, p. 93.

${ }^{13}$ DEBRET,Jean-Baptiste. Viagem pitoresca e histórica ao Brasil, tomo I.São Paulo:Livraria Martins, 1949, p. 151.
} 
rev. hist. (São Paulo), n. 176, a03116, 2017 http://dx.doi.org/10.11606/issn.2316-9141.rh.2017.114417
Silvana Jeha

Ganhar a vida. Uma história do barbeiro africano Antônio José Dutra e sua família. Rio de Janeiro, século XIX
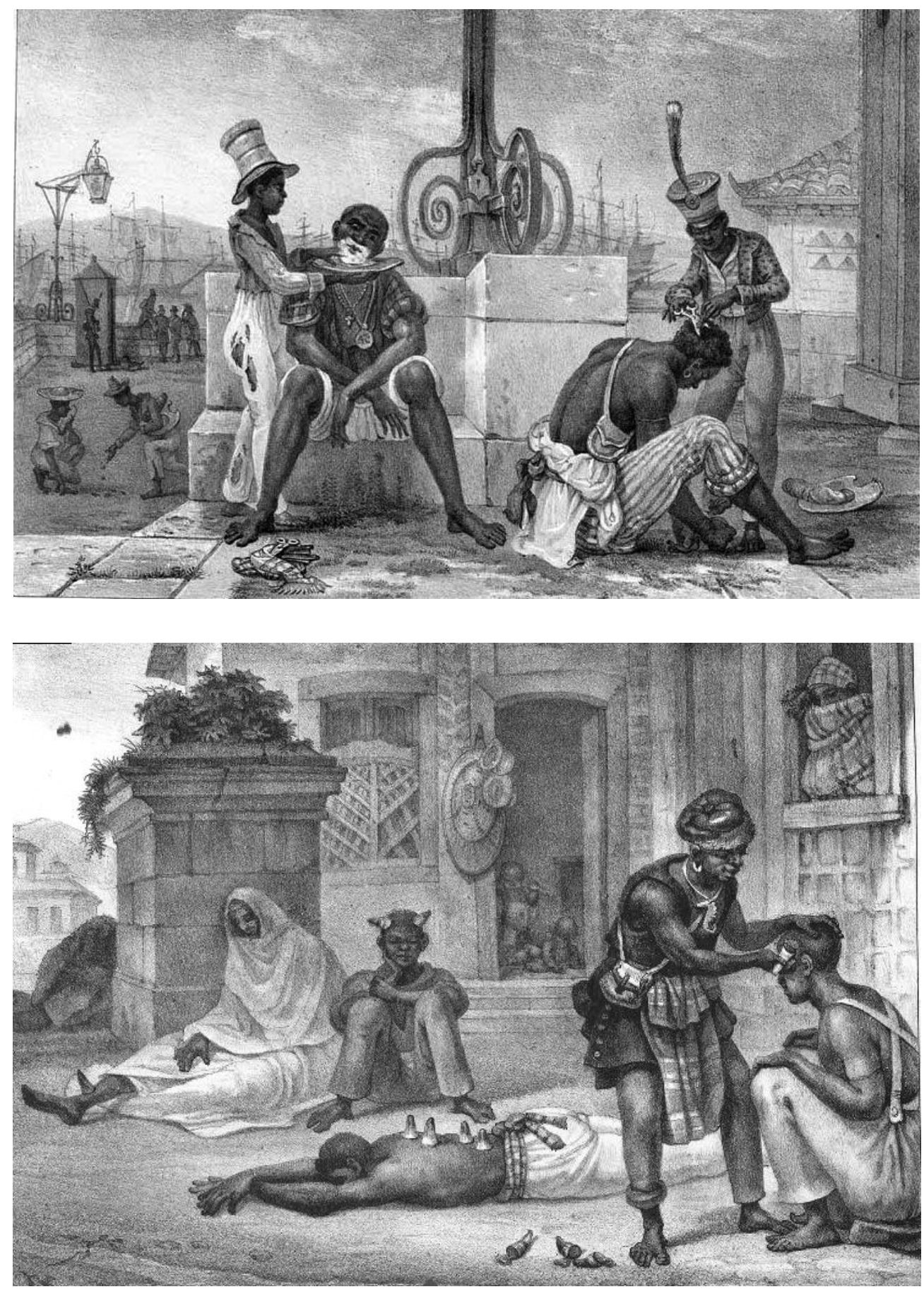

DEBRET, Jean Baptiste [autor da aquarela original]; FRÉRES, Thyers, litogravura. Loja de barbeiro; Barbeiros ambulantes; Cirurgião negro. Litogravura. In: DEBRET, Jean-Baptiste. Voyage historique et pittoresque au Brésil, vol. II. Paris: Firmin Didot Frères, 1835. 
nava a arte de barbeiro a escravos e meninos brancos, além de dar "bichas" aos pobres "de grates", "por amor de Deus". ${ }^{4}$ O germânico Frederico Hubner avisava a seus "fregueses e patrícios" que abria sua loja de barbeiro. ${ }^{15} \mathrm{Ma}-$ dame Gault, mestre parteira, discípula da maternidade de Paris, além de anunciar seus préstimos às parturientes, afirmava "sangrar com perfeição".16 Alguns portugueses barbeiros anunciaram nos jornais sua chegada à Corte, convidando os seus conterrâneos para clientes.

Em 1820, o cirurgião-mor da Fisicatura-mor explicou porque aceitava pedidos de negros para exercer esta arte de cura:

vivendo em um país, onde os homens ingênuos, livres e libertos se negam ao exercício de muitas ocupações, de modo que não há suficiente número de sujeitos nelas peritos, para ocorrer a necessidade pública julguei deveria mais atender esta, (...) e tanto mais porque as Artes de que se trata, tem mais de mecânicas do que de liberais. ${ }^{17}$

Nos anúncios dos jornais, os escravos barbeiros sangradores, frequentemente, eram descritos como bonita, vistosa, elegante figura, possante etc. Estetas, eles provavelmente caprichavam no visual e no seu status de preto ladino. Ladino significava principalmente ser perspicaz. No Vocabulário de Raphael Bluteau (1728), a palavra ladino é sinônima de destro, esperto, “hoje dão os portugueses este mesmo nome aos estrangeiros que falam melhor a sua língua ou a negros que são mais espertos, e mais capazes para o que lhes encomenda". ${ }^{18}$ No ponto de vista senhorial, os negros ladinos correspondiam a esta definição. Para os africanos ser ladino significava ter mais chance de livrar-se da escravidão. João José Reis, autor de algumas biografias sobre africanos bem-sucedidos, criou o termo ladinização. ${ }^{19}$ Num trabalho anterior, Reis sugere que

\footnotetext{
${ }^{14}$ Diário do Rio de Janeiro, 22/7/1824 e 30/9/1824.

${ }^{15}$ Diário do Rio de Janeiro, 20/10/1834.

${ }^{16}$ Diário do Rio de Janeiro, 30/10/1842.

${ }^{17}$ Citado em:PIMENTA, Tania Salgado. Artes decurar:umestudo a partirdos documentos da Fisicatura-morno Brasil do começo do século XIX. Dissertação de mestrado, Departamento de História/IFCH, Unicamp, 1997, p. 91.

${ }^{18}$ BLUTEAU, Raphael. Vocabulario portuguez \& latino: aulico, anatomico, architectonico ..., vol. 5. Coimbra: Collegio das Artes da Companhia de Jesus, 1712-1728, p. 16.

${ }^{19}$ Ver a discussão sobre o debate africanização versus crioulização, além da definição de "ladinização" em REIS, João José. De escravo a rico liberto: A trajetória do africano Manoel Joaquim Ricardo na Bahia oitocentista. Revista de História, n. 174, São Paulo, jan.-jun 2016, p. 6. Concordo com este autor que o termo crioulização aplicado para outras sociedades escravistas não é muito adequado para o Brasil, onde a palavra crioulo era empregada quase exclusivamente para negro nascido no Brasil.
} 
ladino seja entendida quase em seu sentido nativo, válida para todas as gerações de africanos natos que (...) tiveram com o tempo de adaptar, reinventar e criar de novo seus valores e práticas culturais, além de assimilar muitos dos costumes locais, sob as novas circunstâncias e sob a pressão da escravidão deste lado do Atlântico. Os ladinos, no entanto, se adaptaram sem descartar tudo que haviam aprendido do lado de lá do Atlântico. ${ }^{20}$

A ladinização se assemelha ao conceito de transculturação de Mary-Louise Pratt: "como grupos subordinados ou marginais selecionam e inventam a partir de materiais a eles transmitidos por uma cultura dominante ou metropolitana". ${ }^{21}$ Dutra, como os africanos bem-sucedidos biografados por Reis, faz parte de um subgrupo dentre os ladinos: são uma elite negra do ponto de vista econômico, cultural e no mais das vezes religioso. Os ladinos são um grupo bem maior que esta minoria africana que se alforriou, obteve propriedades e proeminência na comunidade negra e alguma respeitabilidade entre os brancos nas grandes cidades do Império. O ladino é o africano escravo ou liberto que, por meio da transculturação, obtém conquistas que diminuem os danos de sua subalternidade social. O "mina-santé" Bonito, provavelmente da etnia achanti, é um africano exageradamente ladino:

Chama-se Carlos, mas dá o nome de Ricardo e é muito conhecido pelo nome de Bonito, foi marinheiro e é pombeiro, (...) vai comprar peixe na Tijuca, em Jacarepaguá e na Lagoa para vender na Cidade, anda muito asseado, inculca-se por forro e é da Irmandade de Santa Ifigênia, esteve proximamente três meses fugido, e foi pegado pelos Capitães do mato, mas pagou para o soltarem; roga-se aos Srs. Comandantes do Registo toda a cautela na saída das embarcações, por ser bom marinheiro.22

\footnotetext{
${ }^{20}$ REIS, João José. Domingos Sodré, um sacerdote africano: escravidão, liberdade e candomblé na Bahia do século XIX. São Paulo: Companhia das Letras, 2008, p. 317.

${ }^{21}$ PRATT, Mary Louise. Os olhos do Império: relatos de viagem e transculturação. Bauru: Edusc, 1999, p. 29.

${ }^{22}$ Diário do Rio de Janeiro, 19/10/1830.
} 
rev. hist. (São Paulo), n. 176, a03116, 2017 http://dx.doi.org/10.11606/issn.2316-9141.rh.2017.114417

\section{Silvana Jeha}

Ganhar a vida. Uma história do barbeiro africano Antônio José Dutra e sua família. Rio de Janeiro, século XIX

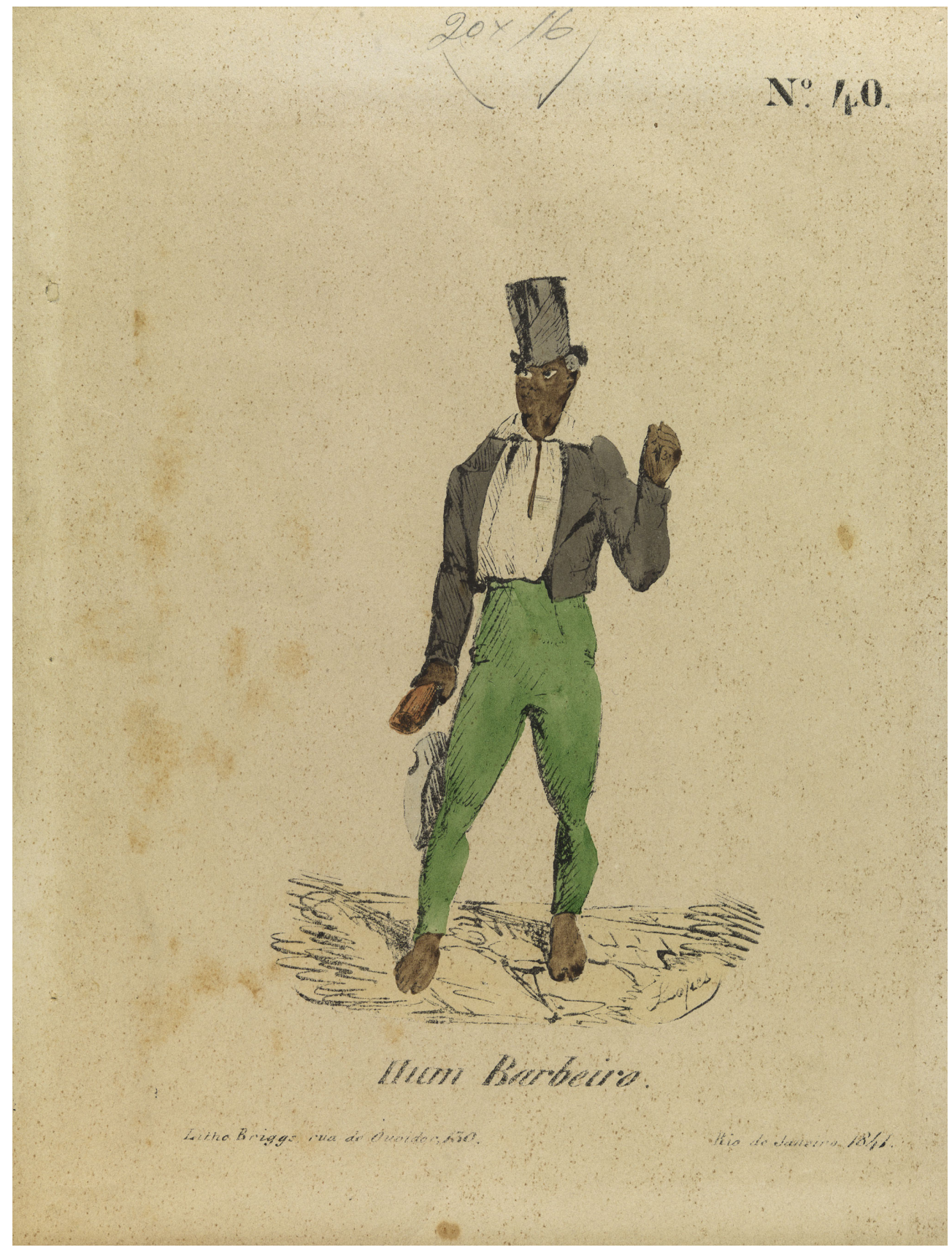

BARROS, Joaquim Lopes de. Hum barbeiro. Lithographia Briggs, 1841. Acervo Biblioteca Nacional. 
Silvana Jeha

Ganhar a vida. Uma história do barbeiro africano Antônio José Dutra e sua família. Rio de Janeiro, século XIX

Um panorama dos escravos barbeiros ladinos verifica-se nos anúncios de jornais:

Vende-se um preto de boa figura e sem vícios com oficio de barbeiro e já prático dos embarques da Costa de Leste [África] e com boa adição de saber ler e escrever. ${ }^{23}$

Vende-se um preto roceiro entendido das plantações do país, assim como fazer farinha, entende de horta em vara, embolsa e cobre casas de palha, enxerta, faz carvão fino, barbeia e sangra, isso à moda de sua terra. ${ }^{24}$

Vende-se (...) um elegante preto de 20 a 22 anos, ótimo dentista, sangrador, bom barbeiro, pajem, entende de boleia e toca rebeca. ${ }^{25}$

Oferece-se um homem barbeiro, sangrador e dentista, bastante carinhoso para tratar de doentes por ter praticado em hospitais, o qual não duvida ir para fora da corte, ou mesmo para alguma loja ou casa particular. ${ }^{26}$

Vende-se um preto perfeito barbeiro e sangrador, apronta lanceta, sabe botar ventosas e bichas, é bom enfermeiro, próprio para qualquer fazenda por ter grande prática de tratar de doentes, sabe tocar flauta e dá-se a contento. ${ }^{27}$

Vende-se um mestre barbeiro bonita figura, bom comportamento, sangra, é dentista, e capaz de dirigir um estabelecimento deste gênero, o que afiançam os seus precedentes; vende-se para a Corte como para qualquer fazenda. ${ }^{28}$

Observa-se na tabela abaixo a origem pan-africana dos barbeiros diplomados, atuantes em sua grande maioria na Bahia e no Rio de Janeiro. Além disso, nas décadas seguintes, nos anúncios de fuga de barbeiros escravos, há grande variedade de nações africanas, além de crioulos e pardos.

\footnotetext{
${ }^{23}$ Diário do Rio de Janeiro, 24/6/1821.

${ }^{24}$ Diário do Rio de Janeiro, 26/7/1825.

${ }^{25}$ Diário do Rio de Janeiro, 13/10/1841.

${ }^{26}$ Diário do Rio de Janeiro, 2/8/1843.

${ }^{27}$ Diário do Rio de Janeiro, 1843.

${ }^{28}$ Diário do Rio de Janeiro, 29/7/1853.
} 
“Nações" dos sangradores africanos registrados na Fisicatura-mor, 1808-1828 ${ }^{29}$

\begin{tabular}{|c|c|}
\hline Região da África & Número de sangradores \\
\hline África ocidental & 46 \\
\hline Mina & 24 \\
\hline Jeje & 19 \\
\hline Calabar & 2 \\
\hline Nago & 1 \\
\hline África centro-ocidental & $\mathbf{5 3}$ \\
\hline Angola & 26 \\
\hline Benguela & 11 \\
\hline Cabinda & 6 \\
\hline Congo & 5 \\
\hline Rebolo & 4 \\
\hline Caçange & 1 \\
\hline África meridional & $\mathbf{2}$ \\
\hline Moçambique & 1 \\
\hline Quelimane & 1 \\
\hline Total & $\mathbf{1 0 1}$ \\
\hline
\end{tabular}

Sabe-se ainda que a maioria proveniente da África ocidental atuou na Bahia (75\%) e os da África centro-ocidental (80\%) na Corte/província do Rio de Janeiro. Estes números correspondem às nações majoritárias em cada uma destas províncias. Na Bahia, a maioria dos escravos havia nascido na África ocidental. No Rio de Janeiro, a maioria no centro-oeste africano. ${ }^{30}$

Outra questão que há em torno dos barbeiros sangradores negros é se esta era uma prática trazida também da África. Num anúncio de venda de escravo transcrito acima o senhor nos informa que seu escravo (sem a nação identificada) pratica sangria "a moda de sua terra". Sim, há registros de prática de sangria no continente do século XVII até hoje.

\footnotetext{
${ }^{29}$ Tabela levemente adaptada de PIMENTA, Tania Salgado. Artes de curar: um estudo a partir dos documentos da Fisicatura-mor no Brasil do começo do século XIX, op. cit., 1997, p. 102-3.

${ }^{30}$ Idem, p. 103.
} 
Silvana Jeha

Ganhar a vida. Uma história do barbeiro africano Antônio José Dutra e sua família. Rio de Janeiro, século XIX

Em São Tomé e Príncipe existe ainda (pelo menos até 2012) o tchiladô ventosa, "pessoas que extraem o 'sangue mau', responsável por inchaços e dores, aplicando ventosas feitas de chifres de boi". ${ }^{31}$ A sangria com chifres foi descrita pelo missionário Giovanni Cavazzi no Reino do Congo no século XVII:

os pretos (...), toscamente aplicam um chifre pequeno e vazio ou uma pequena cabaça, comprimindo-a fortemente sobre a ferida que previamente fizeram e pondo a boca sobre um pequeno furo feito no dito instrumento, chupam com força e extraem assim o sangue até o recipiente ficar cheio. ${ }^{32}$

Na gravura "O cirurgião negro" de Debret, reproduzida acima, as ventosas são feitas com chifre. Segundo o dicionário de medicina popular de Pedro Chernoviz, o mais utilizado no século XIX, as ventosas eram aplicadas com chifres ou vasos de vidro sem hierarquia ou distinção de qualidade.

Em 1865, os falantes de bunda, segundo o minerador Joachim John Monteiro, eram exímios sangradores. Em Cambambe, um deles utilizava lancetas. Haveria muitas sanguessugas nas lagoas de Angola, as quais seriam um importante artigo de exportação para o Brasil. ${ }^{33}$

No entanto, as sanguessugas, eram majoritariamente importadas da Europa, pelo menos no Rio de Janeiro, conforme inúmeros anúncios nos jornais de vendas de "bichas chegadas recentemente" principalmente do Porto, mas também de Hamburgo, Lisboa, Toscana e outros lugares da Europa. No Vocabulário de Raphael Bluteau, a definição de bicha é sinônimo de sanguessuga e o exemplo do termo é Santiago de Faya, freguesia do Conselho de Cabeceiras que se chama

\footnotetext{
${ }^{31}$ MADUREIRA, Maria do Céu. Plantas medicinais e medicina tradicional de S. Tomé e Príncipe. In: Colóquio Internacional São Tomé e Príncipe numa perspectiva interdisciplinar, diacrônica e sincrônica. Actas. Lisboa: ISCTE-IUL, 2012, p. 442. Disponível em: http://cea.iscte.pt/wp-content/ uploads/Actas-STP-Final.pdf. Acesso em: 11 jul 2015.

${ }^{32}$ CAVAZZI. Giovanni Antônio. Descrição histórica dos três reinos do Congo, Matamba e Angola. Lisboa: Junta de Investigações do Ultramar, 1965, p. 145. Mariza Soares sugere que o cirurgião negro da gravura de Debret seria de origem haussa, nupe ou ioruba, grupos étnicos dos atuais $\mathrm{Ni}$ géria e Benin que vieram escravizados para o Brasil e ainda existem na atual Nigéria. Soares baseia a sua hipótese nas pesquisas do antropólogo Lewis Wall feitas na década de 1980 sobre a medicina dos haussas: eles utilizavam chifres para aplicar sangrias e ventosas. Tantos outros também a praticavam na África e no Brasil em tantos tempos e espaços. SOARES, Mariza. African barbeiros in Brazilian slave ports. In: CANIZARES-ESGUERRA, Jorge et alii (ed.). The black urban Atlantic in the age of the slave trade. Philadelphia: University of Pennsylvania Press, 2013, s. p. (ebook).

33 Citado em: SOARES, Mariza. African barbeiros in Brazilian slave ports, op. cit., 2013, p. 7.
} 
vulgarmente Santiago das Bichas, por que em um regato que por ela corre há muitas sanguessugas e desde as primeiras vésperas desse santo até as segundas concorre a ele em romaria muita gente sã e enferma de vários males e uns mandam tirar esses bichos para os porem em si, outros metem as pernas na água e aferrando-se nelas lhes tiram quantidade de sangue, com que se acham melhor e se atribui a milagre do santo, não o pegar das sanguessugas. ${ }^{34}$

Trata-se afinal de mais uma cultura atlântica. A sangria no Rio de Janeiro é de matriz portuguesa certamente transformada pelos africanos de diversas origens que a praticaram. Em determinados lugares de contato, as práticas de sangria na África também podem ter sido transmitidas pelos europeus. Por isso adotei uma abordagem transcultural, atlântica, pan-africana e sincrônica dos sangradores negros no Rio de Janeiro imperial.

\section{Antônio José Dutra}

Antônio José Dutra foi um africano ladino. Executava todas as habilidades dos barbeiros e alforriou-se jovem.

Preto forro. Barbeiro, sangrador, dentista, músico, consertava ossos quebrados. Religioso: membro de três irmandades negras. Morreu líder de banda, dono de uma barbearia, de duas casas e 13 escravos. Viúvo, pai de seis filhos com três mulheres diferentes, a primeira delas escrava Mina, e as outras duas crioulas forras. Quando morreu, seus bens inventariados somaram mais de 15 contos. $^{35}$

Sua casa, no mesmo endereço da barbearia, era mobiliada com sofás, marquesas, mesas e cadeiras. Comia com talheres de prata e dormia em cama. ${ }^{36}$ Quem preparava sua comida era a escrava Carlota Cabinda, alforriada no seu testamento juntamente com o filho Alexandre, cujo prenome era o mesmo de um dos filhos de Dutra. Era patriarca de uma família extensa: o seu compadre José Duarte, por exemplo, declarou até onde iam seus laços de compadrio: "pela muita amizade que tinha com o finado Dutra, este sempre o incumbia da compra de mantimentos para o gasto de sua casa (...) carne seca, toucinho, lombo, feijão etecetera". ${ }^{37}$ Dutra tinha cinco afilhados para quem deixou legados. Muitos dos padrinhos de seus filhos eram seus amigos e acolheram seus afilhados quando da morte do pai.

\footnotetext{
${ }^{34}$ BLUTEAU, Raphael. Vocabulario portuguez E latino, op. cit., 1712, p. 118.

35 Ibidem.

${ }^{36}$ Inventário de Antônio José Dutra, AN, caixa 68, n. 171, p. 38-41.

37 Embargo do inventário de Antônio José Dutra. AN, caixa 1143, n. 4622, p. 83-85.
} 
"Sou católico romano, nasci no Reino do Congo", está escrito no testamento de Dutra, assinado de próprio punho. Capturado para a escravidão, foi batizado na freguesia Nossa Senhora dos Remédios, em Luanda, parte baixa da cidade onde ficavam alojados os escravizados prestes a atravessar o Atlântico. ${ }^{38}$ Acresce que o Reino do Congo manteve estreitas relações com o catolicismo desde o século XVI. Um catolicismo luso-afro-brasileiro constituiu-se ao longo do período colonial - e continuou no imperial - entre os três continentes. Mas foi no Brasil que Dutra viveu o esplendor do que pode ser chamado de catolicismo negro. Tocava em festas religiosas da cidade, era membro de irmandades negras, sendo prior de uma. Quem sabe, devido a seu status social, não atuou como rei do Congo nas congadas e outras festas populares? Na sua casa no Rio de Janeiro, além de uma pequena imagem de São Francisco, havia um oratório onde figuravam três imagens: Cristo na Cruz, Nossa Senhora da Conceição e Santo Antônio. ${ }^{39}$ O barbeiro expressou sua franca devoção a tais santidades, quando depois de alforriar a filha Ignacia de cinco anos rebatizou-a livre como Ignacia Antônia Maria de Jesus Dutra.

Esse catolicismo negro deixou lastro de sua religiosidade na atual umbanda. Nos terreiros de umbanda canta-se um ponto de vovó Cabinda "Meu Santo Antônio é pequenino, auê/Me abre as portas do céu, auê..." As pequenas estátuas de nó de pinho de santo Antônio eram muito populares dentre os escravizados do atual sudeste, a maioria de origem da África central. Robert Slenes observa como elas lembram "as figuras Minkisi da cultura kongo, usadas no baixo rio Congo/Zaire como fetiches para garantir a boa sorte, evitar a desventura". ${ }^{40}$ Segundo ainda este autor, santo Antônio era o santo favorito dos capuchinhos, o grupo de missionários mais perene do Congo, atuantes do século XVII até o XIX. A religiosidade local reinterpretou o santo à sua maneira, tendo no Antonianismo criado pela aristocrata Kimpa Vita, no século XVIII, um culto do catolicismo à moda congolesa com grande aderência popular ${ }^{41}$.

\footnotetext{
${ }^{38}$ REGINALDO, Lucilene. Os rosários dos angolas: irmandades negras, experiências escravas e identidades africanas na Bahia setecentista. Tese de doutorado, Departamento de História/ IFCH, Unicamp, 2005, p. 29.

${ }^{39}$ Inventário de Antônio José Dutra. AN, caixa 68, n. 171, p. 38.

40 SLENES, Robert. "Malungu, ngoma vem!". In: Negro de corpo e alma. São Paulo: Fundação Bienal, 2000, p. 219.

${ }^{41}$ SLENES, Robert. L'arbre nsanda replanté: cultes d'affliction kongo et identité des esclaves de plantation dans le Brésil du sud-est (1810-1888). Cahiers du Brésil Contemporain, n 67/68, 2007, (partie II), p. 250.
} 
Entre seus objetos pessoais havia duas figas de ouro e duas bichas (brincos). Há diversos anúncios de escravos homens que os usavam, inclusive com figas dependuradas. Segundo o viajante americano Thomas Ewbank, o primeiro objeto que um escravo comprava quando tinha dinheiro era uma figa de madeira, de preferência de jacarandá. A figa era um amuleto de origem portuguesa usada por muitos dos habitantes da Corte, negros e brancos. Maria, a parteira portuguesa carola de Memórias de um sargento de milícias, de Manoel Antônio de Almeida, além de um raminho de arruda na orelha e um rosário dependurado no cós da saia, trazia uma figa de osso ou de ouro pregada junto à renda da mantilha. ${ }^{42}$

Antônio José era membro da Irmandade de Santa Ifigênia e Santo Elesbão, fundada por africanos minas no século XVIII. No século seguinte, constituía-se numa entidade crioula e pan-africana: entre 1843 e 1889, um terço dos irmãos era africano. Dentre os africanos a maioria ainda era mina, mas havia congos, angolas, moçambiques. ${ }^{43} \mathrm{Na}$ Bahia, entre os séculos XVIII e XIX, os barbeiros também participavam de múltiplas irmandades, as quais, segundo Nicolau Párés, eram espaços de alianças "étnicas, espirituais, de parentesco e comerciais que reforçaram a articulação de uma elite negra". ${ }^{44} \mathrm{~Pa}-$ rés estudou alguns africanos forros deste período que acumulavam funções de barbeiros, músicos ou regentes de orquestra e milicianos, além de serem membros de irmandades negras. Muitos deles morreram deixando vários escravos como Dutra. ${ }^{45}$

Em 1831, já forro, ele foi um dos signatários da nova versão do Compromisso da Irmandade de Nossa Senhora do Rosário e São Benedito dos Homens Pretos, onde um dos quatro deveres era a alforria dos irmãos escravos. $^{46} \mathrm{O}$ fato de possuir escravos e apoiar iniciativas de alforria não é uma incongruência. O compromisso era pela libertação dos irmãos escravos e não qualquer escravo. Luta-se contra algumas instituições ao mesmo tempo podendo beneficiar-se delas. Possuir escravos naquele tempo e espaço era

\footnotetext{
${ }_{42}$ ALMEIDA, Manoel Antônio de. Memórias de um sargento de milíías. Porto Alegre: LEPM, 2002, p. 40.

${ }^{43}$ OLIVEIRA, Anderson J. M. Santos negros e negros devotos: A Irmandade Santo Elesbão e Santa Efigênia no Rio de Janeiro, século XIX. Cativeiro e liberdade. Rio de Janeiro, UFRJ, jul-dez 1996, p. 41.

${ }^{44}$ PARÉS, Luis Nicolau. Milicianos barbeiros e traficantes numa irmandade católica de africanos minas e jejes (Bahia, 1770-1830). Tempo, vol. 20, 2014, p. 27.

${ }^{45}$ Idem.

${ }^{46}$ Compromisso da Irmandade de Nossa Senhora do Rosário e São Benedito dos Homens Pretos ereta na sua mesma igreja nesta Corte do Rio de Janeiro. Rio de Janeiro: Imprensa do Exército, 1968, cap. I, parágrafo 4.
} 
uma condição sine qua non para prosperar na vida e ter status, algo a que Antônio José dedicou-se com afinco. A escravidão atravessou sua vida de cabo a rabo: foi escravo, deixou de sê-lo, alforriou sua primogênita, teve filhos com africana escrava, crioulas forras, casou-se com uma conterrânea forra. No leito de morte alforriou metade de seus escravos e deixou a outra metade escravizada como legado para seus filhos. Neste jogo de liberdade e escravidão construiu uma biografia entrelaçando as duas.

Dutra era prior da Ordem dos Terceiros de São Domingos. Foi enterrado em sua igreja depois de um grande funeral que custou ao seu inventário cerca de 400\$000 réis. Suas filhas menores despenderam quantias consideráveis em roupas e sapatos novos e muitas missas foram realizadas em pelo menos três igrejas. Ele pediu em seu testamento que fossem rezadas vinte missas pela sua alma. O cura da freguesia do Santíssimo Sacramento e mais sete sacerdotes o encomendaram em casa e acompanharam seu velório até a igreja, onde foi recomendado. ${ }^{47}$ Fora das expensas do inventário, sua filha mais velha ainda gastou com cera e música. Sua morte foi uma festa. ${ }^{48}$

Pertenceu ao grupo dos típicos remediados cariocas e à minoria de africanos vindos como escravos para o Brasil que obtiveram alforria e, dentro dessa minoria, outra que obteve propriedades. Em 1843, Dutra publicou uma nota no jornal acusando um sujeito de ter apresentado uma letra falsa de 600\$000 com sua assinatura. Termina sua indignação com a seguinte assertiva: "Há vinte anos que é estabelecido [com loja de barbeiro], até o presente ainda não se constituiu devedor a pessoal alguma, ao menos do valor de 20 rs., ou cousa semelhante". ${ }^{49}$ Quando faleceu, além de não dever nada, ninguém lhe devia. Era muito comum haver listas de dívidas passivas ou ativas em inventários, o que não aconteceu no inventário de Dutra. Em 1849, ele ganhava a vida ainda com sua música, barbas, costuras, sangrias, extrações de dentes, conserto dos ossos alheios, tudo multiplicado pelo trabalho dos seus 13 escravos e claro, pelo prestígio que obteve desde pelo menos 1823, quando disse ter se estabelecido com loja.

Zephyr Frank contrasta o inventário de Dutra com mais de mil inventários do século XIX e demonstra como o congolês, mesmo sendo uma exceção

\footnotetext{
${ }^{47}$ Arquivo da Cúria Metropolitana do Rio de Janeiro. Livro de óbitos da freguesia do Santíssimo Sacramento, 1849, ap. 168, p. 92.

${ }^{48}$ Referência ao livro de REIS, João José. A morte é uma festa: Ritos fúnebres e revolta popular no Brasil do século XIX. São Paulo: Cia. das Letras, 1991.

${ }^{49}$ Diário do Rio de Janeiro, 31/1/1843.
} 
no que diz respeito à cor, fazia parte de um grupo de cariocas que ele chama de remediados ou detentores de patrimônio mediano no lugar de classe média: "Os remediados constituíam um grupo variado e não há nenhuma razão para suspeitar que um cirurgião-barbeiro como Dutra se considerasse como pertencente à mesma classe que funcionários públicos com o mesmo nível de renda".50 Estes grupos médios, segundo Frank, compartilhavam uma dependência generalizada com o escravismo: os escravos eram base de seus patrimônios pelo menos até a década de $1850 .{ }^{51}$ Isto não explica o porquê do movimento abolicionista ser pífio neste período, mas ajuda a entender.

Dutra pertencia ao grupo socioeconômico de 166 proprietários africanos listados dentre 4.700 proprietários cariocas em 1845, ou seja, três por cento. Na freguesia de Santa Rita, em outra estatística de 1843, onde se indica a ocupação, a quase totalidade de africanos se restringia a barbeiros e quitandeiros. $^{52}$ Estas seriam uma das poucas profissões para um indivíduo forro no Rio de Janeiro ascender economicamente. Dentro deste grupo talvez ele estivesse no topo da pirâmide. Nenhum dos amigos ou companheiras de Dutra alcançou seu sucesso econômico. Um bom exemplo é o padrinho de duas de suas filhas, o mina liberto José Manoel Duarte. Quando morreu, deixou para seus dois filhos uma casa térrea modesta no largo da Sé, uma armação de barraca, tachos e gamelas de cobre. Não tinha escravos e talvez os filhos trabalhassem com os pais na barraca..$^{53}$

Entre as décadas de 1820 e 1840, o preço acessível dos escravos em vários períodos, devido ao grande afluxo legal e ilegal de africanos, possibilitou ascensão social a pobres, inclusive ex-escravos. Isto está evidenciado no depoimento de José Manoel Duarte, o compadre forro de Dutra, sobre quatro alforrias encontradas após sua morte. Disse ser vontade "do referido Dutra que ficassem forros aqueles escravos que lhe tinham ajudado a ganhar a vida". ${ }^{4} \mathrm{O}$ barbeiro, nas décadas seguintes, não teria provavelmente prosperado tanto, pois não conseguiria ter comprado tantos escravos, dadas as mudanças econômicas que o fim do tráfico acarretou. ${ }^{55}$

\footnotetext{
${ }^{50}$ FRANK, Zephyr. Entre ricos e pobres: O mundo de Antônio José Dutra no Rio de Janeiro oitocentista. São Paulo: Annablume, 2012, p. 20.

${ }^{51}$ Ibidem, p. 21.

52 KARASCH, Mary. A vida dos escravos no Rio de Janeiro. São Paulo: Companhia das Letras, 2000, p. 291.

53 Inventário de José Manoel Duarte e Maria da Glória. AN, Juízo da 3ª Vara Municipal, caixa 290, n. 3573.

${ }^{54}$ Embargo do inventário de Antônio José Dutra. AN, caixa 1143, n. 4622, p. 83-85.

55 FRANK, Zephyr, Entre ricos e pobres, op. cit., 2012, p. 21.
} 


\section{A barbearia, a banda}

Tudo indica que Dutra não conseguiu algum documento oficial de sangrador e dentista. Seu nome não está nos registros da Fisicatura-mor na década de 1820. Segundo o próprio, ele teria loja desde 1823, ou seja, manteve o seu negócio por 27 anos. ${ }^{56} \mathrm{~A}$ imensa quantidade de anúncios de jornal e as extensas listagens do Almanack Laemmart fazem crer que havia muito mais barbeiros atuando sem nenhum registro do que registrados.

Antônio chegou a pedir a "competente carta" para a Câmara Municipal em 1831, afirmando estar "há muitos anos estabelecido com sua loja de barbeiro na Rua da Alfândega e exercitando a arte de sangrador e dentista, por ter aprendido com mestre aprovado". ${ }^{57}$ Mas seu pedido não foi atendido, com a observação: "não tem loja". ${ }^{58}$ Em 1845, ele não figura numa lista de terapeutas de saúde com carta registrada na Câmara. ${ }^{59}$ Possivelmente o mestre aprovado referido por ele fosse José Dutra, preto forro que adquiriu carta de cirurgião barbeiro da Fisicatura-mor em $1808 .{ }^{60}$ Frequentemente os forros adotavam os nomes de seus ex-proprietários. ${ }^{61}$ Se isto for verdade, a "dinastia" Dutra de barbeiros negros atravessou o século XIX carioca como veremos mais adiante.

Na loja, havia 16 cadeiras, cinco penteadores, almofariz, bigorna, martelo, pedras para afiar as navalhas, bacias, mangas de vidro, três barris para água, o que demonstra o grande afluxo do lugar. Foram listadas diversas peças de ferro para tirar dentes no inventário.

Cinco clientes poderiam fazer a barba ou cortar o cabelo ao mesmo tempo, e sobrava mais uma dezena de cadeiras para os demais clientes esperarem, ou receberem outros serviços, por exemplo, sangrias. Os escravos não ocupados com barbas e cabelos poderiam afiar ferramentas, pregar botões

\footnotetext{
${ }^{56}$ Em 1843, Dutra, num anúncio de jornal, afirmou que mantinha a barbearia na rua da Alfandega havia 20 anos, ou seja, teria se instalado ali em 1823, três anos antes de se casar. Diário do Rio de Janeiro, 31/10/1843.

57 Arquivo Geral da Cidade do Rio de Janeiro. Sangradores e dentistas, códice 50-1-5.

${ }^{58}$ Relação dos srs médicos, cirurgiões, boticários, sangradores e parteiras que têm as suas cartas registradas na ilm.a Câmara Municipal desta cidade, conforme disposto no par. 10, tit. 20a , seção $1^{\mathrm{a}}$, das posturas. Diário do Rio de Janeiro, 13/11/1845.

${ }^{59}$ Diário do Rio de Janeiro, 13/11/1845.

${ }^{60}$ AN, Fisicatura-mor, códice 145, vol. 1, p. 53v -54.

${ }^{61}$ Zephyr Frank sugere outro dono: Antônio José Rebello, dono de sua filha primogênita bem como da mãe dela, Josefa Mina.
} 
(pelo menos um dos escravos de Dutra era alfaiate), aplicar sangrias a domicílio ou mesmo tocar um instrumento para animar o ambiente.

Os treze escravos adultos de Dutra eram de diversas nações: oito provenientes da África centro-ocidental: um rebolo, um congo, dois cabindas, três benguelas e um angola; e cinco provenientes da África meridional: dois moçambiques e três quelimanes. ${ }^{62}$

Joaquim Rebolo, 40 anos, Joaquim Congo, 30, Domingos Moçambique, 46, Felipe Moçambique, 30, Antônio Quelimane, 28, e a cozinheira Carlota Cabinda, 25, com seu filho Alexandre de 19 meses, foram alforriados quando Dutra morreu. Os dois Joaquim adotaram o nome de Dutra: Joaquim Antonio Dutra e Joaquim José Dutra. ${ }^{63}$ Um dos escravos, José Benguela, fugiu durante o processo do inventário alegando que também merecia ser alforriado, já que fazia o mesmo serviço daqueles que foram. O tutor das crianças não perdoou: recapturado e detido na Casa de Correção logo voltou às suas funções de escravo. ${ }^{64}$

Os escravos mais novos e menos íntimos continuaram cativos e cada filho herdou um, com exceção de Ignacia que herdou dois. Depois de 1849 os escravos herdados pelos filhos menores foram por algum tempo capitaneados pelo compadre de Dutra, o barbeiro Antônio Fernandes da Silva. Silva foi testamenteiro, inventariante e tutor dos filhos de Dutra, os quais afirmou tratar "como filhos". Era igualmente membro da Irmandade de Nossa Senhora do Rosário e Ordem Terceira de São Domingos de Gusmão.

A barbearia de Dutra ainda funcionou por cerca de um ano. Antônio Fernandes da Silva anunciava nos jornais aplicação de bichas nos endereços de sua barbearia na rua da Lapa e a dos seus tutelados na rua da Alfândega. João Baptista, marido de Ignacia, filha primogênita de Dutra - então em processo de divórcio eclesiástico - acusou o tutor de má administração do que restou da loja de barbeiro. Reclamou que ele alugava os instrumentos legados por Dutra para os libertos tocarem fora da cidade. No seu ponto de vista, o certo seria o filho Manoel, então maior de 18 anos, se apossar dos instrumentos e abrir sua própria loja, a exemplo do que fizeram os ex-es-

\footnotetext{
${ }^{62}$ Inventário de Antônio José Dutra. AN, caixa 68, n. 171, p. 38-41.

${ }^{63}$ Idem.

${ }^{64}$ Ibidem, p. 121. Uma história correlata ocorreu em 1824: um barbeiro anunciou no Diário do Rio de Janeiro que vendia seu escravo "oficial de barbeiro que pode servir de mestre a qualquer loja, de nação Benguela, que não quer servir a seu senhor por ser da sua cor." Diário do Rio de Janeiro, 18/7/1824.
} 
Silvana Jeha

Ganhar a vida. Uma história do barbeiro africano Antônio José Dutra e sua família. Rio de Janeiro, século XIX

cravos. Manoel, por sua vez, reclamou que Silva estava retendo metade dos $\$ 800$ réis cobrados pelas aplicações de sanguessugas. ${ }^{65}$

Fernandes talvez se sentisse no direito de, como mestre, seguir a prática de pagamento das barbearias descrita pelo advogado de João Baptista:

É costume que existe entre barbeiros desta corte, quando mestres com casa aberta, tendo diferentes gavetas com tantas outras fendas por cima das quais ele mestre é o claviculário, logo que o mês é findo, abre-se na vista de todos quantos ali depositaram o estipêndio de seus respectivos trabalhos; e partindo-o com o dono da casa que lhes fornece almoço e jantar e cear, sendo daí que demanda o gasto do pão diário (...), sendo este o modo pelo qual deve o inventariante formular as contas dos rendimentos da referida casa ou loja n. 163 da Rua da Alfândega. ${ }^{66}$

O barbeiro explicou a má performance da barbearia do falecido Dutra, fechadaemnovembrode1850, diferentedasua, quefuncionou atépelomenos 1874:

Não demonstro o emprego de três mil réis [quantia que disse gastar por dia com os cinco menores] e para todos os misteres de custeio da casa que não tem recibo como carne, peixe, despesa de armazém secos e molhados, lavadeira e engomadeira e 21 galinhas entre elas muitas de $1 \$ 200$ a $1 \$ 400$ réis, 30 e tantos frangos que comprei para os enfermos, que nos três meses de fevereiro a maio [de 1850] sempre tive pessoa da família doente, principalmente das febres que reinam [amarela], que chegariam a estar todos de cama a um tempo, tanto os cinco menores como os escravos deles. Motivo este, que não pude logo pô-los em praça o que ainda o custeio necessário para o tráfico da loja. ${ }^{67}$

O inventariante contratou oficiais de barbeiro Felisberto e João dos Passos e os dois Joaquim alforriados. Um deles, Joaquim Antônio Dutra, chegou a receber $450 \$ 000$ réis entre janeiro e novembro de 1850, quase metade do total de gastos da barbearia no mesmo período. Ao mesmo tempo, os ex-escravos de Dutra constituíram banda independente. Além de contratados para tocar fora da cidade, abriram uma barbearia na rua do Fogo. Joaquim Antônio Dutra, anos depois, abriu sua própria barbearia na rua de São Pedro. ${ }^{68}$

\footnotetext{
${ }^{65}$ FRANK, Entre ricos e pobres, op. cit., 2012, p. 160.

${ }^{66}$ Inventário de Antônio José Dutra. AN, caixa 68, n. 171, p. 140-2.

${ }^{67}$ Ibidem, p. 80. Entre janeiro e maio de 1850, a febre amarela atingiu 9.600 pessoas, das quais 4.160 morreram. KARASCH, Mary. A vida dos escravos, op. cit., p. 222.

68 Almanak Laemmert, 1855, p. 567.
} 


\begin{abstract}
A música
Antes das dez horas da manhã, a música de barbeiros marchava, indo postar-se na baixada a Igreja [Glória, RJ]. Dessa banda, a principal, era diretor um certo Dutra, mestre de barbeiros da Rua da Alfandega, que a ensaiava e fardava para as mais ruidosas funções. Todas as figuras eram negros escravos; o uniforme não primava pela elegância, nem pela qualidade. Trajavam jaqueta de brim branco, calça preta, chapéu branco alto e andavam descalços. Os que não sabiam de cor a parte, liam-na pregada a alfinetes nas costas do companheiro a frente, que servia de estante.

A procura desses artistas era extraordinária. Ainda na noite antecedente a banda havia acompanhado a procissão da Boa-Morte, que saía da Igreja do Hospício, procissão obrigada a irmandades. ${ }^{69}$
\end{abstract}

A chamada música de barbeiros também é registrada no período colonial, principalmente na Bahia, e é também um legado europeu. ${ }^{70}$ Durante o período colonial e imperial, era executada majoritariamente por africanos e seus descendentes, mas os brancos também o faziam. Segundo o viajante norte-americano Thomas Ewbank: "A banda da Lapa é composta de barbeiros brancos, que são famosos como violinistas e tocadores de clarim".71 Apesar de na banda de Dutra não haver instrumentos de corda, vários anúncios de venda de escravos nos jornais ofereciam barbeiros que tocavam rebeca. ${ }^{72}$

O livro de gastos da irmandade do Santíssimo Sacramento da igreja da Candelária entre 1770 e 1834 é um registro importante da participação de músicos negros nas festas católicas. A partir de 1780, há pagamentos para "timbaleiros negros"; "pretos timbaleiros"; "música dos Henriques". Enfim, variadas maneiras de se referir às bandas de negros. Luiz Nicolau Parés demonstrou que neste mesmo período havia uma elite de barbeiros negros da Bahia os quais muitas vezes eram membros de irmandades negras e oficiais das milícias de negros, ou terço de Henriques como estas eram chamadas. Na sequência de denominações de bandas de negros que tocaram na Paróquia do Santíssimo Sacramento do Rio de Janeiro observa-se "Mú-

\footnotetext{
${ }^{69}$ MORAIS FILHO, Mello. Festas e tradições populares do Brasil. Brasília: Senado Federal, 2002 [1901], p. 186. ${ }^{70}$ Ver: TINHORÃO, José Ramos. Música de barbeiros (estudos com bibliografia). In: Idem. Música popular: um tema em debate. $3^{a}$ edição revista e ampliada. São Paulo: Editora 34, 1997, p. 127-144; PARÉS, Luís Nicolau. Milicianos barbeiros e traficantes, op. cit., 2014, p. 1-32; ALVES, Marieta. Música de barbeiros. Revista Brasileira de Folclore, vol. 7, n. 17, 1967, p. 5-13.

${ }^{71}$ EWBANK, Thomas. Vida no Brasil ou diário de uma visita à terra do cacaueiro e da palmeira. Belo Horizonte: Itatiaia Editora, 1976, p. 191.

72 PARÉS, Luís Nicolau. Milicianos barbeiros e traficantes, op. cit., 2014, p. 32.
} 
Silvana Jeha

Ganhar a vida. Uma história do barbeiro africano Antônio José Dutra e sua família. Rio de Janeiro, século XIX

sica de Henriques" como um dos nomes das bandas de negros. As milícias negras foram aos poucos extintas nos anos iniciais do Império do Brasil. ${ }^{73}$ Entre 1818 e 1828, o timbaleiro José Dutra recebeu em média $20 \$ 000$ réis pela "música dos pretos"; "música de timbaleiros em domingo da ressurreição e corpo de Deus"; e "música da porta da igreja".74 Como já notei acima, suponho que José Dutra, preto forro, era o provável proprietário de Antônio José Dutra. Anos mais tarde, em 1834, quando não havia mais registro de seu antecessor, Antônio recebeu $19 \$ 200$ dessa irmandade pela "música da porta da igreja" durante a semana santa. ${ }^{75}$

No inventário do barbeiro estão listados: dois bombos, quatro tambores, dois pratos, quatro clarinetas, uma requenta grande, uma corneta de chaves, um pistom e duas trompas com defeito. ${ }^{76} \mathrm{O}$ conjunto foi avaliado em 81\$000, quantia muito baixa, levando-nos a crer que eram instrumentos de menor qualidade, ou muitos velhos. Talvez, como aponta José R. Tinhorão, fossem instrumentos de segunda mão das bandas militares. ${ }^{77}$ No entanto, eles eram fundamentais para o que foi o maior lucro da barbearia depois de sua morte: a banda. As bandas de Dutra, de seu antecessor e de seus sucessores marcaram presença em muitas festas da cidade em todo o século XIX.

Na gravura de Thomas Ewbank abaixo, publicada em Vida no Brasil, podemos ver uma banda composta por negros que tocam bumbo, trompa, flauta ou clarinete e um instrumento que parece uma corneta ou um clarim.

\footnotetext{
75 PARÉS, Luis Nicolau. Milicianos barbeiros e traficantes, op. cit., 2014.

74 "Livros 4, 5 e 6 "de receita e despesa do Santíssimo Sacramento da Irmandade de Nossa Senhora da Candelária". Transcritos em LANGE, Francisco Curt. Pesquisas esporádicas de musicologia no Rio de Janeiro. Revista do IEB, vol. 4. São Paulo, 1968, p. 130-142.

${ }^{75}$ Ibidem, p. 142.

${ }^{76}$ Inventário de Antônio José Dutra. AN, caixa 68, n. 171, p. 38-41. Na Bahia, no inventário do barbeiro Jeje Joaquim Cardoso da Costa estavam listados três clarinetes travesseiros, dois ditos portugueses, um pífano, uma flauta, duas trompas, um clarim com suas competentes voltas, um zabumba, uma caixa e um par de pratos, "tudo muito velho, avaliado em 12 mil réis". PARÉS, Luis Nicolau. Milicianos barbeiros e traficantes, op. cit., 2014, p. 20.

77 TINHORÃO, José Ramos. Música de barbeiros, op. cit., 1997, p. 144.
} 


\section{Silvana Jeha}

Ganhar a vida. Uma história do barbeiro africano Antônio José Dutra e sua família. Rio de Janeiro, século XIX

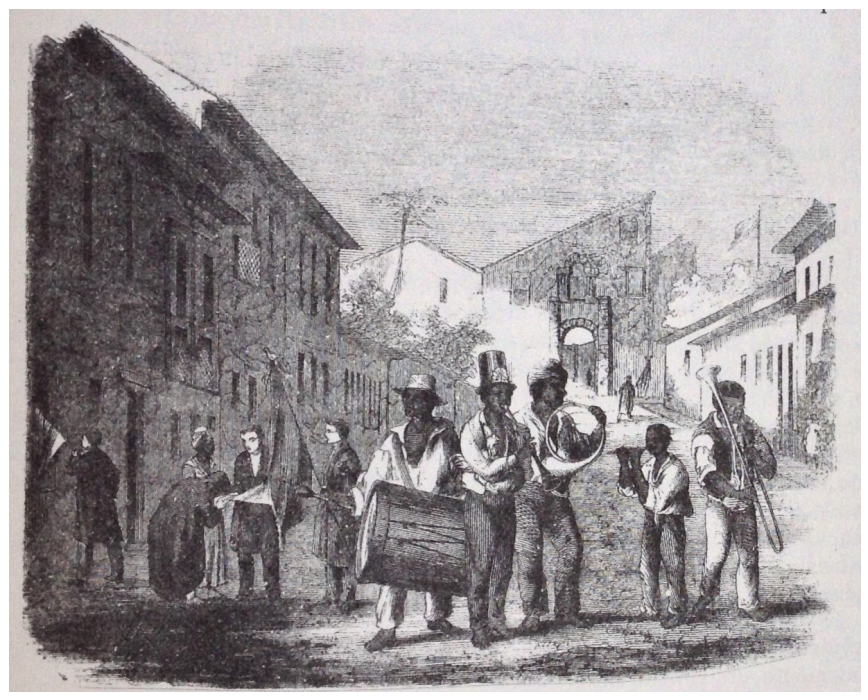

"Uma banda de negros, consistindo de dois corneteiros, três tambores, uma clarineta e um flautim emergiam e recomeçavam a tocar uma valsa". Sobre a coleta de esmolas para a festa do Divino Espírito Santo em 17 de abril de 1846 no Catete, Rio de Janeiro. A gravura publicada no livro de Ewbank foi publicada originalmente no livro de BUVELOT, Louis $\mathcal{E}$ MOREAU, Auguste. Brazil pitoresco de 1845. In: EWBANK, Thomas. Life in Brazil. Nova York: Harpers \& Brothers, 1856, p. 250.

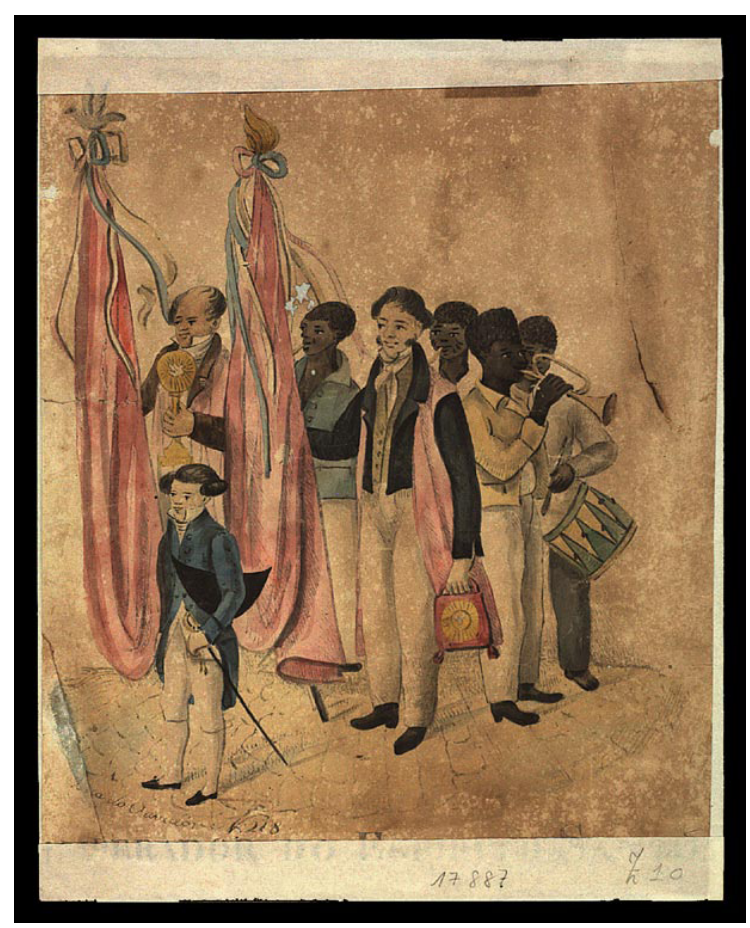

BRIGGS, Frederico Guilherme. Procissão, c. déc. 1830. Gravura. A banda de negros acompanha a procissão do Divino Espírito Santo na rua do Ouvidor. Acervo Biblioteca Nacional. 
Depois da morte de Dutra, entre janeiro e outubro de 1850, a música rendeu mais de um conto de réis, o dobro das "barbas e demais trabalhos de ofícios de barbeiros", ${ }^{78}$ mesmo não tendo funcionado nos meses de fevereiro, março e junho e ter experimentado um período de decadência, já que os oficiais ganharam a liberdade e os escravos que restaram foram acometidos pela febre amarela.

Na novela Memórias de um sargento de milícias, durante a Festa do Divino Espírito Santo, "apenas se ouvia a fanhosa música de barbeiros, tudo corria à janela para ver passar a folia". ${ }^{79}$ A banda era descrita como "meia dúzia de aprendizes ou oficiais de barbeiro, ordinariamente negros, armados este com um pistão desafinado, aquele com uma trompa diabolicamente rouca, formavam uma orquestra desconcertada, porém estrondosa, que fazia as delícias dos que não cabiam ou não queriam estar dentro da igreja". ${ }^{80}$ A música foi descrita como valsas e contradanças por Debret, ou dobrados, quadrilhas e fandangos por Mello Morais Filho. Em 1866, na Bahia, a música do barbeiro Marcos na Festa do Bonfim foi chamada de lundu pelo jornal 0 Alabama. ${ }^{81}$ Lundu era palavra polissêmica, podia ser uma dança e variados ritmos de influência ibérica e africana misturada no Brasil. A música de barbeiros era a música das ruas, a música popular influenciada por todos os populares da cidade e executada principalmente por africanos e seus descendentes, assim como o ofício de barbeiro sangrador.

Toda a segunda parte da peça A família e a festa na roça, de 1837, de Martins Pena, se passa numa Festa do Divino e traz nos versos finais o canto de um folião explicitando a relação íntima entre fé e farra, os lundus sendo executados entrecortados pelos sinos da igreja:

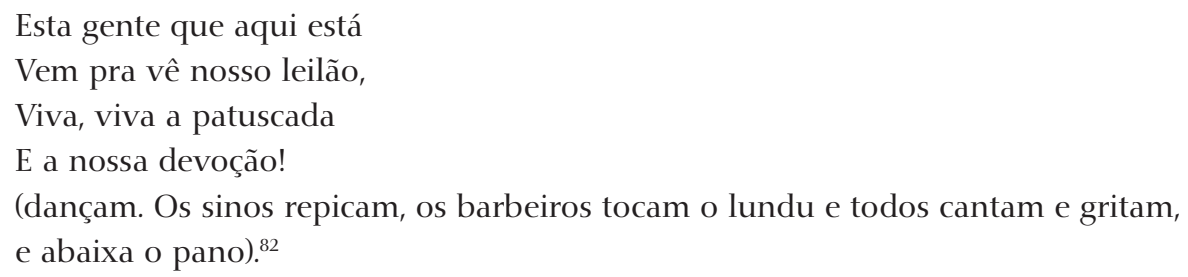

\footnotetext{
${ }^{78}$ Inventário de Antônio José Dutra. AN, caixa 68, n. 171, p. 80.

${ }^{79}$ ALMEIDA, Manuel Antônio. Memórias de um sargento de milícia, op. cit., p. 95.

${ }^{80}$ Ibidem, p. 70.

${ }^{81}$ PARÉS, Luís Nicolau. Milicianos barbeiros e traficantes, op. cit., 2014, p. 17.

82 PENA, Martins. Comédias (1833 - 1844), vol. 1. Organizado por Vilma Arêas. São Paulo: Martins Fontes, 2007, p. 138.
} 
José Ramos Tinhorão afirma que, diferente da música das bandas militares e suas herdeiras civis dos coretos, a música de barbeiros constitui um

som que se perdeu. Mas que ao morrer assim sem memória, talvez tenha passado em espirito à música do choro, através da sobrevivência de algo do seu "ritmo de senzala" dos negros escravos, misteriosamente incorporado a sestrosidade manhosa dos mestiços da baixa classe média carioca, por isso mesmo chamados de chorões. ${ }^{83}$

Em 1936, o chorão memorialista Alexandre Pinto relacionou diversos músicos chorões atuantes desde a década de 1870. Eles tocavam, além de diversos instrumentos de cordas e todos os instrumentos de sopro da banda de Dutra, principalmente o clarinete. São funcionários e trabalhadores - carteiros, guardas municipais, operários - do subúrbio ou periferia do centro, como se tornaram os filhos de Dutra. Os chorões tocavam em festas particulares, religiosas também como Manoel e Alexandre. ${ }^{84}$

Na década de 1870, Alexandre e Manoel foram membros administrativos e certamente músicos da Sociedade Feliz Aurora Musical, uma "banda particular" que tocou em eventos como: uma recepção a general Osório, herói da guerra do Paraguai; a formatura de alunos de uma liga operária; a inauguração de um hotel em Santa Teresa; um evento beneficente no Campo de Santana para as vítimas da seca do Ceará de 1877; uma missa de sétimo dia de um padre do curato do Santíssimo Sacramento, para quem o pai também prestou serviços musicais décadas antes. Também promovia bailes. ${ }^{85}$ Manoel ainda pertencia à Sociedade Beneficente Bons Amigos União do Bonfim. ${ }^{86}$ Os filhos herdaram do pai além da musicalidade a prática associativa.

\section{A família}

Pouco se sabe sobre as companheiras de Antônio José. Menos ainda sobre Maria Roza de Jesus, natural da "costa leste do Congo" 87 como o marido, e ex-escrava de Ana Joaquina. Casou-se aos 25 anos com o conterrâneo, à época com 27 e já forro. A cerimônia aconteceu na igreja do Sacramento às

\footnotetext{
${ }^{85}$ TINHORÃO, José Ramos. Música de barbeiros, op. cit., 1997, p. 144.

${ }^{84}$ PINTO, Alexandre Gonçalves. O choro: reminiscências dos chorões antigos. Rio de Janeiro, 1936.

${ }^{85}$ Gazeta de Notícias, 8/7/1877 e 21/7/1877; O Globo, 22/1/1877; Diário do Rio de Janeiro, 1/7/1877; O Apóstolo, 2/5/1877; Jornal do Commercio, 12/5/1877.

${ }^{86}$ Diário do Rio de Janeiro, 7/2/1870.

87 "Costa leste" era uma expressão corrente para se referir à África.
} 
cinco horas da tarde do dia 2 de julho de $1824 .^{88}$ Maria Roza faleceu provavelmente na década de 1830.

Com a escrava Josefa Mina teve a filha Ignacia, em 1822. Ele não menciona Josepha no testamento, mas seu nome consta na primeira certidão de nascimento da menina. Em 1861, já forra, Josepha Thereza Ribeiro reaparece num anúncio de jornal convidando a todos para o funeral da filha.

Com a crioula forra Hilária, também chamada de Laura Maria do Rosário, Dutra teve os filhos Manoel e Alexandre. O relacionamento ocorreu na década de 1830.

Teúda e manteúda" por Dutra - segundo a própria - e mãe de três de seus filhos, a crioula forra Ana Maria Mathildes era uma jovem de 22 anos quando o pai das crianças faleceu. Deu luz às três filhas a partir dos 16 anos. Do pai das filhas não herdou nenhum tostão. Depois de falecer a caçula Frutuosa, aos três anos, obteve no Juízo de Órfãos a parte da herança que cabia à filha, usada imediatamente para pagar uma dívida de mais de 700\$000 réis. Morreu aos 29 anos, tuberculosa. Foi enterrada na vala comum do cemitério da Santa Casa de Misericórdia. ${ }^{89}$

Dutra mencionou ainda o nome da misteriosa Rosa Benguela em seu testamento como "uma negra que mora em minha companhia", Ihe legando

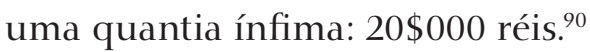

Em 1830, Dutra rebatizou sua filha primogênita Ignacia que passou a se chamar Ignacia Antônia Maria de Jesus Dutra. Quando do primeiro batismo da menina, em 2 de setembro de 1822, dias antes da chamada Independência do Brasil, constava na certidão do livro de batismos de escravos da freguesia do Santíssimo Sacramento simplesmente Ignacia e os nomes de sua mãe, a escrava Josefa Mina; do padrinho, o forro José Antônio de Carvalho; da madrinha, a escrava Faustina e do dono da menina, Antônio Jose Rebello. ${ }^{11}$ Este mesmo senhor Rebello, mediante $128 \$ 000$ réis em maio de 1827, a libertou "para todo o sempre, como se forra nascesse do ventre materno".92 Antônio José Dutra preparou sua segunda certidão de batismo, registrada no livro de

\footnotetext{
${ }^{88}$ Habilitação matrimonial de Antônio José Dutra e Maria Rosa de Jesus. Arquivo da Cúria Metropolitana do Rio de Janeiro (ACMRJ), caixa 2821, doc. 65299, 1824.

${ }^{89}$ Inventário de Maria Mathildes Dutra. AN, caixa 4212, n. 1851, f. 56.

90 Testamento de Antônio José Dutra, op. cit. AN, caixa 2680, n. 341.

91 Embargo..., op. cit., fl. 74.

${ }^{92}$ Registro de um papel de liberdade que dá Antônio José Ribeiro [Rebello] a sua escrava Ignacia em 14/5/1827. In: Embargo..., op. cit., fl. 72-3.
} 
batismo de livres da freguesia do Sacramento, meses antes dela casar com o crioulo forro João Baptista Moreira da Silva. ${ }^{93}$

Alforriada aos cinco anos, depois de algum tempo, foi morar como agregada na casa do "Cavaleiro de uma das três Ordens do Império" tenente Saturnino. Segundo a própria Ignacia, à época

\begin{abstract}
andava em colégios, e se foi para a sua casa foi a instâncias do mesmo para acabar de aprender com uma filha do mesmo de nome Maria Saturnina do Loreto, asseverando-lhe que com ela aprenderia também a música e tocar piano, a que ela conveio e assim anuiu seu pai. Não obstante este não contribuir com mensalidades, contudo lhe mandava mantimentos. ${ }^{94}$
\end{abstract}

Ao que parece, Ignacia teria vivido muitos anos na casa da mestra, filha do tenente, que lhe teria ensinado a ler, escrever e tocar piano, subsidiada pelo pai. Aos 18 anos se casou com o pedreiro João Baptista Moreira da Silva - também filho de uma africana e crioulo forro - na igreja de São Domingos, em 23 de novembro de 1839.95 O casal morou em alguns endereços, pagando aluguel no valor de 6 a $8 \$ 000$ réis até se acomodarem definitivamente, sem custos, numa das casas de Dutra na rua do Saco do Alferes. ${ }^{96}$ Segundo Ignacia, o pai lhe preparara um enxoval para o casamento. Logo depois da cerimônia, quando se mudou para a casa de marido, levou "uma cômoda de jacarandá e um baú onde acomodava as suas roupas, uma negrinha de nome Gertrudes emprestada pelo pai para vender os doces que fazia". ${ }^{97}$ José Manoel Duarte, compadre de Dutra, era encarregado de entregar-lhe as comedorias do dia-a-dia, remédios da botica de Luiz de tal e galinhas quando estava enferma, além de uma mesada paterna de $4 \$ 000$ réis mensais, pois o esposo João Baptista não lhe proveria com o devido sustento. A esposa em litígio afirmou que, enquanto estavam casados, ele ganhava como pedreiro $1 \$ 600$ de diária e que realizava várias empreitadas de 100\$, 200\$, 300\$ mil réis e, mesmo assim, não lhe sustentava. ${ }^{9}$

Ignacia declarou que o marido a "tratava pior que uma escrava", além de ameaçá-la de morte. Alegou que seu casamento não se desfizera antes, pois o

\footnotetext{
${ }_{95}$ Livro de casamentos de livres da freguesia do Santíssimo Sacramento, 1839. ACMRJ, AP. 135.

${ }^{94}$ Embargo..., op. cit., fl. 86.

${ }^{95}$ ACMRJ. Livro de casamentos de livres da Freguesia do Santíssimo Sacramento, 1839, AP. 135, p. $116 \mathrm{v}$.

${ }^{96}$ Atual rua América, situada atrás da estação Central do Brasil no bairro de Santo Cristo.

${ }^{97}$ Embargo..., op. cit., fl. 86.

${ }^{98}$ Idem, fl. 86-9.
} 
pai achava que "lhe seria vergonhoso", por isso só iniciou o libelo de divórcio no Juízo Eclesiástico após a morte de Dutra. Depois de alguns anos, a sentença final favorável a Ignacia resume os motivos da consumação do divórcio:

\begin{abstract}
Adultérios pelo réu cometidos, amancebando-se com uma Maria Crioula e depois com outra de nome Rosa Cabinda com quem hoje vive e passa dias, noites repartindo com ela o jornal que ganha quando trabalha, que por semelhante cousa tem seviciado a autora não só com maus tratos, ameaças de assassiná-la, nomes injuriosos e como com falta do necessário sustento e vestuário do que por seu pai Antônio José Dutra hoje falecido dando-lhe até escrava para a servir e uma casa na rua do Saco para com o réu morar, dos quais maus-tratos resultou ter ela autora abortado por três vezes. ${ }^{99}$
\end{abstract}

Uma das testemunhas do processo do divórcio depôs ter visto o pedreiro na casa de Rita Cabinda, na rua Senhor dos Passos, em mangas de camisa. Ignácia depôs ter sido informada por um aprendiz do marido que João Baptista e Maria Crioula foram juntos para um procissão de quarta-feira de cinzas. João Baptista e seus procuradores atacavam Ignacia nos depoimentos e nas margens dos processos judiciais, xingando-a de "miserável criatura", "foco de bodum", "casadinha desonesta", coquete, lambeta. Ignacia ainda declarou que "o réu nunca a maltratou de pancadas talvez por respeito a seu pai, porém descompunha com palavras injuriosas bem como mandá-la a puta que a pariu e outras que tais".100 Um procurador de João Baptista chegou a publicar uma carta no Diário do Rio de Janeiro com o intento de desmoralizá-la, chamando-a de pagadeira barregã de Antônio Fernandes da Silva, testamenteiro e inventariante do pai. ${ }^{101} \mathrm{Na}$ margem de um dos processos lê-se que Ignacia era "uma indotada tirada da cozinha do seu Senhor logo na idade de cinco anos (...) criada por favor e esmola na casa do Cavaleiro Saturnino como por amor a Deus até completar a idade de dezoito anos".102 $\mathrm{O}$ advogado de Ignacia respondeu finamente a este comentário: "não vem a outro fim mais que para deprimir a autora, pois bem se vê que a condição e a circunstância de ter nascido cativa e depois liberta a não privou de seus direitos".103

\footnotetext{
${ }_{99}$ Embargo..., op. cit., p. 112-3.

${ }^{100}$ Idem.

${ }^{101}$ Barregã significa concubina e pagadeira seria aquela que sustenta alguém. Diário do Rio de Janeiro, 14/4/1851.

${ }^{102}$ Idem, p. 67.

${ }^{103}$ Inventário por traslado, Ignacia Maria Antônia de Jesus Dutra x João Baptista Moreira da Silva. AN, caixa 4122, n. 17, fl. 7-13.
} 
João Baptista era um crioulo forro filho de escrava. Ignacia era negra, mulher e forra, o que a posicionava abaixo dele na pirâmide social. Mesmo alguém tão próximo da sua condição social poderia espezinhá-la, pois afinal seria fácil destruir uma mulher negra forra, agora sem proteção paterna, deprimindo-a, desmoralizando-a. Mas não. João Baptista foi varrido de sua vida afetiva e financeira. O divórcio se consumou em 1856. Finalmente naquele ano, o auto de partilha do casal se deu e somava dois escravos, móveis e instrumentos musicais. Gertrudes continuou pertencendo a Ignacia e Antônio Quelimane passou a pertencer a João Baptista. ${ }^{104}$

Ignacia nasceu escrava em 1822, filha da escrava Josefa Mina e de Antônio José que devia estar forro ou prestes a se alforriar. Foi criada como agregada na casa de um tenente, pai da mestra que lhe ensinou as letras e piano. Em 1850, João Baptista afirmou que a ex-esposa tinha em seu poder um piano e uma viola do tenente Saturnino além de "diferentes peças de música e quadrinhas impressas". ${ }^{105}$ Casou-se com um homem violento, mulherengo, que a desrespeitava. Recebeu do pai patriarca carinho e sustento. Levou a cabo um processo de divórcio desgastante nos anos de 1850. Depois da morte do pai, não havia mais marido, nem tenente, era ela e sua família extensa, que incluía padrinhos, a mãe, meios-irmãos e provavelmente uma vasta comunidade católica negra. Quando morreu em 1861, sua mãe, Josepha Thereza Ribeiro, já forra, seus quatro irmãos e cunhado anunciaram juntos seu funeral, demonstrando que a família não se dissipara com a morte do pai. O séquito partiu da rua das Violas no centro até o cemitério São Francisco Xavier (Caju), sugerindo que ela tinha algum prestígio social. A missa de sétimo dia aconteceu na igreja de São Pedro. ${ }^{106}$

Forra, filha de forros, observa-se que Ignacia não abriu mão, por mais de quinze anos, de possuir Gertrudes, denominada quitandeira, além de Antônio Quelimane, barbeiro que manteve por sete anos. Durante o processo de divórcio, em 1856, João Baptista cobrou os rendimentos mensais por sete anos dos dois escravos que pertenceriam ao casal. Se seus cálculos foram corretos, Gertrudes renderia $12 \$ 000$ réis mensais e Antônio, $24 \$ 000$ réis. ${ }^{107}$ Certamente Ignacia viveu principalmente do trabalho de seus escravos. É

\footnotetext{
${ }^{104}$ Inventário por traslado do divórcio de Ignacia M. A. J. Dutra e João Baptista M. da Silva, caixa 4122, n. 17, fl. 90

${ }^{105}$ Inventário por traslado do divórcio de Ignacia M. A. J. Dutra e João Baptista M. da Silva, caixa 4122, n. 17, fl. 23-4.

${ }^{106}$ Correio Mercantil, 10/09/1861.

${ }^{107}$ Idem..., fl. 18.
} 
possível que tenha complementado a renda como musicista, tocando nos teatros e festas da cidade.

Ignacia Maria morreu aos quarenta anos, junto de sua mãe africana, meios irmãos e outros membros da extensa família Dutra, os quais, negros como ela, inventavam a vida possível dos brasileiros dessa cor tão íntima da escravidão naquela sociedade escravista.

Manoel José Dutra e Alexandre José Dutra tinham 16 e 14 anos quando o pai morreu. Segundo o tutor, Manoel, o mais velho era oficial de barbeiro, porém "vadio". Alexandre aprendia o oficio de dourador numa loja perto da casa onde morava com a mãe. Cada um dos meninos herdou um escravo, os quais trabalharam em torno de um ano até serem vendidos. Herdaram do pai uma casa na rua do Saco do Alferes que rendia $16 \$ 000$ réis por mês de aluguel, portanto $8 \$ 000$ réis para cada, quantia próxima aos $7 \$ 000$ réis por mês arbitrado pelo juiz de órfãos a cada um para atender os custos de comedorias, vestir e calçar. ${ }^{108}$

As perspectivas profissionais de negros livres eram, em geral, os mesmos ofícios mecânicos dos escravos. Os mestiços tinham mais chance de ascender socialmente. Nesta década de 1850, o jovem Joaquim Maria Machado de Assis, neto de libertos, filho de pintor de paredes e de uma açoriana branca, começou a trabalhar cedo como aprendiz de tipógrafo na Imprensa Nacional e publicou, aos 16 anos, um poema num jornal. ${ }^{109}$ Além de escritor e jornalista renomado, tornou-se funcionário público de médio porte, profissões que lhe possibilitariam frequentar meios de classe média e elite. Diferente do negro, o mulato poderia chegar a ser visto como branco e o passado escravo ser praticamente apagado. Machado nasceu socialmente pardo, neto de pardos forros e morreu, segundo o registro de óbito, branco. Depois de sua morte, Joaquim Nabuco, que fora abolicionista, admirou-se de José Veríssimo tê-lo chamado de mulato e lhe escreveu: "O Machado para mim era um branco, e creio que por tal se tomava; quando nele houvesse sangue estranho isto em nada afetava a sua perfeita caracterização caucásica".110 Outros mulatos tiveram ascensões semelhantes. Certamente não estava nos planos de seu tutor e, nem no de seu pai, a possibilidade de seus pupilos estudarem numa das recém-fundadas faculdades do Império.

\footnotetext{
${ }^{108}$ Inventário de Antônio José Dutra. AN, caixa 68, n. 171.

${ }^{109}$ MASSA, Jean-Michel. A juventude de Machado de Assis 1839-1870. Ensaio de biografia intelectual. Rio de Janeiro: Civilização Brasileira, 1971.

${ }^{110}$ Carta de Joaquim Nabuco a José Veríssimo, Washington, 25/11/1908. Fundação Joaquim Nabuco.
} 
O personagem barbeiro branco "Compadre" de Memórias de um sargento de milícias sonhava um grande futuro, longe do seu ofício de barbeiro, para o seu filho de criação, cujos pais biológicos eram portugueses. "Fazia castelos no ar a seu respeito". Ensinou-lhe a ler e escrever, pois sonhava ver o afilhado tornar-se um clérigo:

\begin{abstract}
Gastava às vezes as noites em fazer castelos no ar a seu respeito; sonhava-lhe uma grande fortuna e uma elevada posição (...) (pensava ele) (...) Pelo meu ofício... Verdade é que arranjei-me (...) porem não o quero fazer escravo dos quatro vinténs dos fregueses... seria talvez bom mandá-lo ao estudo... Porém para que diabo serve o estudo? (...) Letrado: Era bom... sim, letrado... mas não; não tenho zanga a quem me lida com papéis e demandas... Clérigo?... um senhor clérigo é muito bom (...) ganha-se muito... Pode vir um dia a ser cura. Está dito, há de ser clérigo ora... ${ }^{11}$
\end{abstract}

Os dois irmãos participaram, na década de 1870, da Sociedade Musical Feliz Aurora como descrito acima. Provavelmente não foi dali que tiraram sustento, mas certamente este pertencimento lhes dava algum prestígio social.

Manoel José foi sacristão na igreja de São Domingos em 1850 e seguiu a carreira de barbeiro e músico. Não sei se tinha bens, mas ganhava a vida com o que seu pai lhe transmitiu: a profissão. Entre 1876 e 1877, aparece nas listas de qualificação de votantes como letrado e casado, ora sua profissão é artista, ora barbeiro, morando nas freguesias de Santa Rita e Sacramento. ${ }^{112}$ Sua renda anual era $650 \$ 000$.

Alexandre José Dutra era, pelo menos a partir da década de 1870, guarda municipal na freguesia de Santo Antônio e depois na de Santana, ganhando $400 \$ 000$ réis anuais segundo a lista de qualificação de votantes de 1877. Era, como o irmão, letrado e casado (talvez amasiado, não está claro). Teve com Luiza de Andrade seis filhos: Alexandre, Raul, Ignácio, Maria, Laura e Júlia, reconhecidos e perfilhados. Uma tragédia abateu a família e os quatro primeiros faleceram ainda menores. Luiza deixou o marido quatro meses antes dele morrer, o que o levou a escrever um testamento bastante melancólico. ${ }^{113}$ Moravam em casa própria na rua Silva Rego ou Engenho de Dentro, estação

\footnotetext{
${ }^{111}$ ALMEIDA, Manuel Antônio de. Memórias de um sargento..., op. cit., p. 25.

${ }^{112}$ Diário do Rio de Janeiro, 1/7/1876 e 27/1/1877 entre outras datas.

${ }^{113}$ Se creditarmos a denúncia da irmã Leopoldina Mathildes em 1870, é possível supor que Alexandre era um homem agressivo. Ela publicou um anúncio no Jornal do Commercio declarando que Alexandre a espancara por causa de um lenço "chegando a ponto de dar-me com o calçado no rosto e pontapés no estômago, do que estou bem mal; parece-me que, se não fossem as pessoas que moram na casa, matar-me-ia". Jornal do Commercio, 17/9/1870.
} 
de trem do Riachuelo, além de possuírem terrenos em Cascadura. Alexandre morreu em 1888, aos 54 anos, poucos meses antes da proclamação da República. No seu testamento, pediu para que fosse rezada uma missa de sétimo dia por sua alma e, no mesmo dia, uma para o seu "pai natural" Antônio José Dutra e para sua mãe que disse se chamar Laura e não Eulália, como está na sua certidão de batismo (nem tampouco Hilária como aparece no testamento de seu pai). Era sócio remido da Sociedade União Funerária $1^{\mathrm{o}}$ de Junho, a qual deveria proceder a seu enterro, além de ser membro da Ordem de São Domingos de Gusmão, em cuja igreja fora enterrado seu pai. ${ }^{114}$

A vida de Alexandre, expirada no Engenho de Dentro, alude para o romance Clara dos Anjos de Lima Barreto. A história da família Dutra, iniciada com uma associação com o romance Memórias de um sargento de milícias, passou neste ponto a esboçar o mundo das linhas suburbanas da Estrada de Ferro da Central do Brasil, cenário do romance de Lima Barreto vinte anos depois. Da área central da cidade, pobres, miseráveis, funcionários públicos de baixo escalão, operários foram migrando para os bairros adjacentes às estações como o personagem Lafões, guarda como Alexandre e também morador do Engenho de Dentro. ${ }^{115}$

Após a morte do pai, as meninas Leopoldina de 7 anos e Maria Mathildes, de 6 anos frequentaram a mestra d. Antônia Maria da Conceição, a quem pagavam $4 \$ 000$ réis por mês. Cada uma das três filhas herdou um escravo e um terço de uma casa no Saco do Alferes.

A caçula Frutuosa morreu em 1851, aos 3 anos. Seu enterro custou menos de $20 \$ 000$ réis. Dois anos antes, nos gastos do funeral de mais de 400\$000 réis de seu pai, foram descontados $68 \$ 000$ destinados ao luto de Frutuosa. ${ }^{116}$ Levada numa cadeirinha de aluguel, vestida com hábito de cetim da Ordem de Nossa Senhora da Conceição de Boa Morte, foi velada num caixão alugado e enterrada no campo santo do Caju numa cova de $1 \$ 440$ réis, preço, por exemplo, de uma galinha. ${ }^{117}$ A casa que herdou com as irmãs estava alugada por $30 \$ 000$ réis, o que cobria a quantia de $9 \$ 000$ réis mensais para cada uma das três meninas a fim de serem gastos com "comedorias, vestir e calçar".118

\footnotetext{
${ }^{114}$ Notificação para prestar contas da testamentária, 1890. Alexandre José Dutra - falecido. AN, Inventários, caixa 469, n. 1872.

${ }^{115}$ BARRETO, Lima. Clara dos Anjos. São Paulo: Companhia das Letras, 2011.

${ }^{116}$ Inventário de Antônio José Dutra. AN, caixa 68, n. 171, p. 47.

${ }^{117}$ Ibidem, p. 126-9.

${ }^{118}$ Ibidem, p. 86.
} 
Na década de 1850, Leopoldina obteve emancipação e retirou do cofre do Juízo a quantia de $642 \$ 000$ réis, o que deve ter lhe ajudado a começar a vida. ${ }^{119}$

Maria Mathildes casou-se, menor de idade, com Estevão Barrozo Pereira, negro e filho natural como ela, com quem teve a filha Cândida Barrozo Dutra. Ela manteve, até morrer aos 36 anos em 1880, a parte da casa da rua Saco do Alferes que herdou do pai em 1849. Uma missa de seis meses de sua morte foi realizada na igreja Nossa Senhora do Rosário e São Benedito. ${ }^{120}$ Seu marido faleceu quatro anos depois e foi enterrado como indigente. Cândida ainda conseguiu recuperar da herança dos pais algo em torno de 500\$000 réis, à época uma quantia muito pequena. Casou-se com o gaúcho de Bagé Francisco Vianna das Chaves em 1888 e foi morar no Engenho Novo, subúrbio da Central do Brasil, como seu tio Alexandre. ${ }^{121}$

\section{Epílogo?}

Antônio José Dutra mudou seu destino, mas não o sistema, pelo contrário, se valeu dele. No entanto, sua atuação junto com outros africanos e afrodescendentes ajudou a criar um mundo negro mais autônomo. Se suas diversas companheiras não foram favorecidas pela sua ascensão, a não ser indiretamente por meio dos filhos, estes, aos trancos e barrancos, se beneficiaram de seus legados materiais e imateriais ganhando a vida mais humildemente, porém com mais recursos econômicos e sociais que outros forros e negros. A epopeia extraordinária de uma minoria ínfima de africanos bem-sucedidos durante o escravismo é uma página dessa história que está sendo escrita por alguns historiadores devido à desproporcional existência de documentação a seu respeito. É necessário fazer esta história do excepcional atenta e criticamente.

Antônio José morreu juntamente com o fim do período mais intenso de chegada de escravos africanos no Brasil. Transitou por dois continentes, dois status econômicos, escravidão e liberdade. Foi testemunha do processo de independência do Brasil. Alguns de seus filhos viram a república ser proclamada. Cada uma dessas polaridades se misturava o tempo todo.

As trajetórias dos filhos de Dutra correspondem a uma realidade mais compartilhada, ainda que minoritária, e oferecem o exemplo de como o

\footnotetext{
${ }^{119}$ Embargo..., op. cit., p. 189 e 212.

${ }^{120}$ Gazeta de Notícias, 5/8/1880.

${ }^{121}$ Inventário de Maria Mathildes Dutra. AN, caixa 4212, n. 1851.
} 
acesso a um pequeno pecúlio lhes garantiu uma posição socioeconômica menos vulnerável. O fato deles possuírem algum dinheiro para começar a vida e terem recebido alguma educação formal e atenção à saúde na infância possibilitou, sobretudo aos homens, acesso ao voto, à moradia, trabalho e formas de associativismo. Enfim, cidadania rara entre os negros de sua época e longe de estar universalizada para os negros de hoje em dia.

\section{Referências bibliográficas}

ALMEIDA, Manoel Antônio de. Memórias de um sargento de milícias. Porto Alegre: LEPM, 2002.

BARRETO, Lima. Clara dos Anjos. São Paulo: Companhia das Letras, 2011.

BLUTEAU, Raphael. Vocabulario portuguez E latino: aulico, anatomico, architectonico ... Coimbra: Collegio das Artes da Companhia de Jesus, 1712 - 1728.

CAVAZZI. Giovanni Antônio. Descrição histórica dos três reinos do Congo, Matamba e Angola. Lisboa: Junta de Investigações do Ultramar, 1965.

Compromisso da Irmandade de Nossa Senhora do Rosário e São Benedito dos Homens Pretos ereta na sua mesma igreja nesta Corte do Rio de Janeiro. Rio de Janeiro: Imprensa do Exército, 1968.

DEBRET, Jean-Baptiste. Viagem pitoresca e histórica ao Brasil, tomo I. São Paulo: Livraria Martins, 1949.

EWBANK, Thomas. Vida no Brasil ou diário de uma visita à terra do cacaueiro e da palmeira. Belo Horizonte: Itatiaia Editora, 1976.

FARIAS, Juliana Barreto; SOARES, Carlos Eugênio Líbano; GOMES, Flávio. No labirinto das nações: africanos eidentidades no Rio de Janeiro. Rio de Janeiro: Arquivo Nacional, 2005.

FERREIRA, Luiz Otávio. Medicina impopular - ciência médica e medicina popular nas páginas dos periódicos científicos (1830-1840). In: CHALHOUB, Sidney et alii (org.). Artes e ofícios de curar no Brasil: capítulos de história social. Campinas: Editora da Unicamp, 2003.

FRANK, Zephyr. Entre ricos e pobres: O mundo de Antônio José Dutra no Rio de Janeiro oitocentista. São Paulo: Annablume, 2012.

GUimARÃES, dr. Duas palavrinhas acerca da peritonite. Archivo Medico Brasileiro. Rio de Janeiro, outubro de 1845.

KARASCH, Mary. A vida dos escravos no Rio de Janeiro. São Paulo: Companhia das Letras, 2000.

LANGE, Francisco Curt. Pesquisas esporádicas de musicologia no Rio de Janeiro. Revista do IEB, vol. 4, 1968.

MADUREIRA, Maria do Céu. Plantas medicinais e medicina tradicional de São Tomé e Príncipe. In: COLÓQUIO INTERNACIONAL SÃO TOMÉ E PRÍNCIPE NUMA PERSPECTIVA INTERDICISPLINAR, DIACRÔNICA E SINCRÔNICA. Actas. Lisboa: ISCTE-IUL, 2012, p. 442. Disponível em: http://cea.iscte.pt/wpcontent/uploads/Actas-STP-Final.pdf. Acesso em: 11 jul 2015. 
MASSA, Jean-Michel. A juventude de Machado de Assis 1839-1870. Ensaio de biografia intelectual. Rio de Janeiro: Civilização Brasileira, 1971.

MORAIS FILHO, Mello. Festas e tradições populares do Brasil. Brasília: Senado Federal, 2002 [1901].

OLIVEIRA, Anderson J. M. Santos negros e negros devotos: A Irmandade Santo Elesbão e Santa Efigênia no Rio de Janeiro, século XIX. Cativeiro e liberdade. Revista interdisciplinar de História, UFRJ, jul-dez 1996.

PARÉS, Luis Nicolau. Milicianos barbeiros e traficantes numa irmandade católica de africanos minas e jejes (Bahia, 1770-1830). Tempo, vol. 20, 2014.

PENA, Martins. Comédias (1833 - 1844), vol. 1. Organizado por Vilma Arêas. Rio de Janeiro: Martins Fontes, 2007.

PIMENTA, Tânia Salgado. Barbeiros-sangradores e curandeiros no Brasil (18081828). Manguinhos - história, ciências, saúde, vol. 5, n. 2, jul-out-1998.

. Artes de curar: um estudo a partir dos documentos da Fisicatura-mor no Brasil do começo do século XIX. Dissertação de mestrado, Departamento de História, Unicamp, 1997.

PIMENTA, Tania S. E DANTAS, Rodrigo A. Barbeiros-sangradores no Rio de Janeiro oitocentista: Transformações de um ofício. Revista da ABPN, vol. 6, n. 14, jul-out, 2014.

PINTO, Alexandre Gonçalves. O choro: reminiscências dos chorões antigos. Rio de Janeiro, 1936.

PRATT, Mary Louise. Os olhos do Império: relatos de viagem e transculturação. Bauru: Edusc, 1999.

REGINALDO, Lucilene. Os rosários dos angolas: irmandades negras, experiências escravas e identidades africanas na Bahia setecentista. Tese de doutorado, Departamento de História, IFCHS, Unicamp, 2005.

REIS, João José. De escravo a rico liberto: A trajetória do africano Manoel Joaquim Ricardo na Bahia oitocentista. Revista de História, n. 174, São Paulo, jan.-jun 2016.

Domingos Sodré, um sacerdote africano: escravidão liberdade e candomblé na Bahia do século XIX. São Paulo: Companhia das Letras, 2008.

RUSSEL-WOOD, A. J. R. Escravos e libertos no Brasil colonial. Rio de Janeiro: Civilização Brasileira, 2005.

SANTOS, Georgina Silva dos. A arte de sangrar na Lisboa do Antigo Regime. Tempo, vol. 10, n. 19, Rio de Janeiro, jul 2005.

SLENES, Robert. "Malungu, ngoma vem!". In: Negro de corpo e alma. São Paulo: Fundação Bienal, 2000.

SLENES, Robert. L'arbre nsanda replanté: cultes d'affliction kongo et identité des esclaves de plantation dans le Brésil du sud-est (1810-1888). Cahiers du Brésil Contemporain, n 67/68, 2007, (partie II), p. 217-313.

SOARES, Mariza. African barbeiros in Brazilian slave ports. In: CANIZARES-ESGUERRA, Jorge et alii (ed.). The black urban Atlantic in the age of the slave trade. Philadelphia: University of Pennsylvania Press, 2013, s. p. (ebook).

TINHORÃO, José Ramos. Música de barbeiros (estudos com bibliografia). In: Idem. Musica popular: um tema em debate. $3^{\text {a }}$ edição revista e ampliada. São Paulo: Editora 34, 1997.

Recebido: 15/04/2016 - aprovado: 23/09/2016 